\title{
1 Dual-ion delivery for synergistic angiogenesis and bactericidal capacity with silica-based microsphere
}

4 Khaliun Boldbaatar ${ }^{a, b, \#}$, Khandmaa Dashnyam ${ }^{a, b, c, \#}$, Jonathan C. Knowles ${ }^{\text {b,c,d,e }}$, HaeHyoung Lee a,c,f, Jung-Hwan Lee $^{\mathrm{a}, \mathrm{c}, \mathrm{f}, *}$, Hae-Won Kim ${ }^{\mathrm{a}, \mathrm{b}, \mathrm{c}, \mathrm{f}, *}$

7 anstitute of Tissue Regeneration Engineering (ITREN), Dankook University, Cheonan 8 330-714, Republic of Korea

9 bepartment of Nanobiomedical Science \& BK21 PLUS NBM Global Research Center

10 for Regenerative Medicine, Dankook University, Cheonan 330-714, Republic of Korea

11 'UCL Eastman-Korea Dental Medicine Innovation Centre, Dankook

12 University, Cheonan, Republic of Korea

13 Division of Biomaterials and Tissue Engineering, Eastman Dental

14 Institute, University College London, London, UK

$15{ }^{\mathrm{e}}$ The Discoveries Centre for Regenerative and Precision Medicine,

16 Eastman Dental Institute, University College London,

17 London, UK

18 fDepartment of Biomaterials Science, College of Dentistry, Dankook University,

19 Cheonan 330-714, South Korea

\#KB (khaliun1209@gmail.com) and KD (handmaa@naver.com) contributed equally to

23 this paper as first authors.

$24 *$ Co-corresponding authors: JHL (ducious@gmail.com), HWK (kimhw@dku.edu)

25 Jung-Hwan Lee, DDS, PhD, Researcher, Institute of Tissue Regeneration Engineering

26 (ITREN), Dankook University, Cheonan 330-714, Republic of Korea,

27 Tel: +82 41550 3081; Fax: +82 41559 7839; E-mail: ducious@gmail.

28 Hae-Won Kim, PhD, Professor, Institute of Tissue Regeneration Engineering (ITREN),

29 Dankook University, Cheonan, Republic of Korea

30 Tel: +82 41550 3081; Fax: +82 41559 7839; E-mail: kimhw@dku.edu 
Abstract

2 Inhibition of bacterial growth with the simultaneous promotion of angiogenesis has been

3 challenging in the repair and regeneration of infected tissues. Here, we aim to tackle this

4 issue through the use of cobalt-doped silicate microspheres that can sustainably release

5 dual ions (silicate and cobalt) at therapeutically-relevant doses. The cobalt was doped up

6 to $2.5 \mathrm{wt} \%$ within a sol-gel silicate glass network, and microspheres with the size of $\sim 300$

$7 \mu \mathrm{m}$ were generated by an emulsification method. The cobalt and silicate ions released

8 were shown to synergistically upregulate key angiogenic genes, such as HIF1- $\alpha$, VEGF

9 and the receptor KDR. Moreover, the incorporation of ions promoted the polarization,

10 migration, homing and sprouting angiogenesis of endothelial cells. Neo-vascular

11 formation was significantly higher in the dual-ion delivered microspheres, as evidenced

12 in a chicken chorioallantoic membrane model. When cultured with bacterial species, the

13 cobalt-doped microspheres effectively inhibited bacteria growth in both indirect or direct

14 contacts. Of note, the bacteria/endothelial cell coculture model proved the efficacy of

15 dual-ion releasing microcarriers for maintaining the endothelial survivability against

16 bacterial contamination and their cell-cell junction. The current study demonstrates the

17 multiple actions (proangiogenic and antibacterial) of silicate and cobalt ions released

18 from microspheres, and the concept provided here can be extensively applied to repair

19 and regenerate infected tissues as a growth factor- or drug-free delivery system.

20 Keywords: Ion delivery, cobalt/silicate, angiogenesis, antibacterial, multifunctional

21 biomaterials

\section{Statement of significance}

24 While several ions have been introduced to biomaterials for therapeutic purposes, 25 relaying the effects of antibacterial into tissue regenerative (e.g., angiogenesis) has been a 26 significant challenge. In this study, we aim to develop a biomaterial platform that has the 27 capacity of both 'antibacterial' and 'proangiogenic' from a microsphere sustainably 28 releasing multiple ions (herein cobalt and silicate). Here, dual-actions of the microspheres 29 revealed the stimulated endothelial functions as well as the inhibited growth of different 
1 bacterial species. In particular, protecting endothelial survivability against bacterial

2 contamination was reported using the bacterial/endothelial co-culture model. The current

3 concept of drug-free yet multiple-ion delivery biomaterials can be applicable for the

4 repair and regeneration of infected tissues with dual actions of angiogenesis and

5 suppressing bacterial activity.

\section{Graphical abstract}

7 Dual ions (silicate and cobalt ions) released from microspheres promote angiogenesis

8 while simultaneously inhibiting bacteria growth, as demonstrated by the salvaged

9 survivability of endothelial cells against bacterial contamination. The multiple ion-

10 delivery microspheres can be potentially useful for the repair and regeneration of infected

11 tissues as a drug-free biomaterial platform.

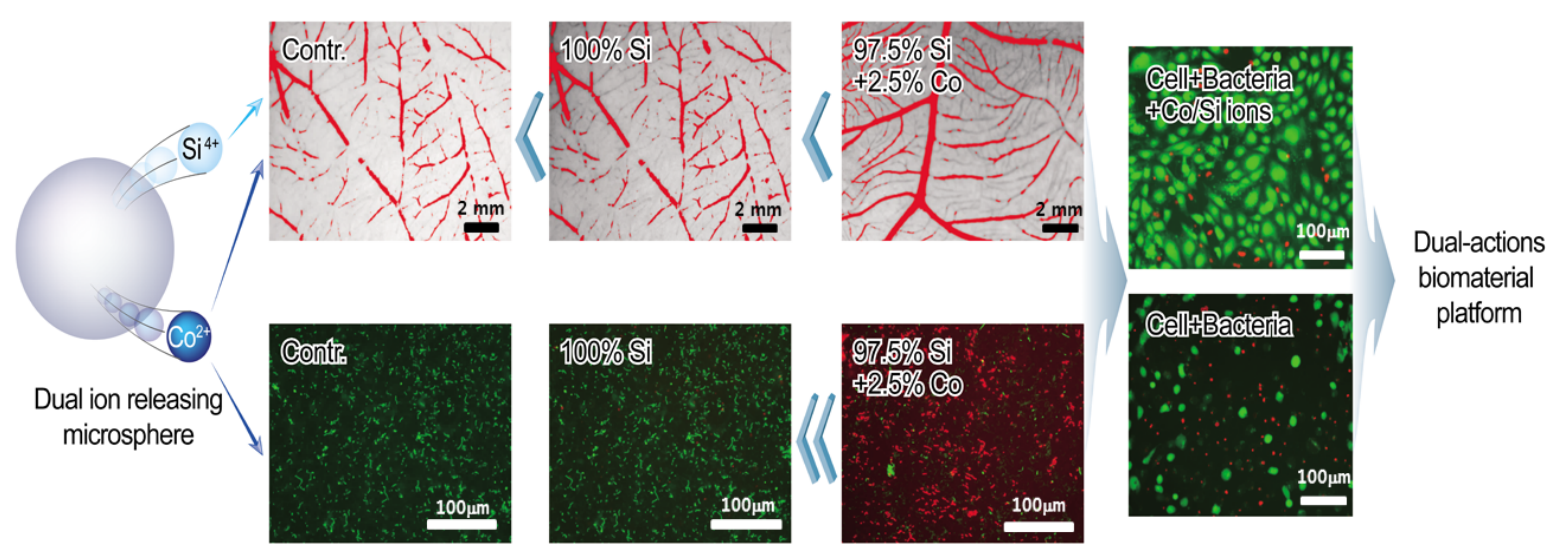


Introduction

The delivery of therapeutics such as drugs or biomolecules that can promote tissue functions is considered an effective strategy to engineer biomaterials for

4 regenerative medicine [1-3]. Recently, ions have been highlighted as the therapeutic

5 components of biomaterials [4,5]. For example, treating damaged tissues with angiogenic

6 ions (i.e., Si ions) was effective in accelerating tissue regeneration through neo-vascular

7 formation [6,7]. In fact, myriad therapeutic ions $\left(\mathrm{Ag}^{+}, \mathrm{Ca}^{2+}, \mathrm{Cu}^{2+}, \mathrm{Co}^{2+}, \mathrm{Mg}^{2+}, \mathrm{Sr}^{2+}\right.$, and

$8 \mathrm{Zn}^{2+}$ ) have been doped into biomaterials at proper doses to target other therapeutic 9 functions such as stimulating cell proliferation, controlling cell differentiation, and 10 relieving inflammation [8-11]. However, synergistic or combined effects from different 11 ions delivered by biomaterials have not been investigated in detail, although this delivery 12 can mimic the microenvironment in the human body, where many ions play roles in 13 tissue regeneration [12].

14 A significant hurdle for tissue regeneration often arises from bacterial infection,

15 which mitigates the tissue healing/repair process and results in limited regeneration [13].

16 Clinical therapies generally involve treatment with antimicrobial drugs or surgical 17 removal of infected tissues [14,15]. However, complications are often encountered,

18 including the insufficient function of administered or locally injected antibiotic drugs, 19 incomplete removal of infected tissues due to anatomical complexities, and the limited

20 bactericidal/bacteriostatic effects without additional therapeutic functionality [16].

21 In case of regeneration of infected tissue, the body naturally reacts to disease-causing 22 bacteria by increasing local blood flow along with the stimulated angiogenesis 23 intrinsically (from infected site to outer region) and extrinsically (from outer region to 24 infected site) and recruiting immune cells to destroy the bacteria[17] . But, when initial 25 angiogenesis is not processed in the infected site due to the destruction of proangiogenic 26 precursors in surrounding area, the delay of tissue repair/regeneration is inevitable due to

27 insufficient clearance of pathogens and consequent accumulation of toxins, deteriorating 28 angiogenesis for the infected tissue regeneration [18]. Therefore, in case of accelerating 29 regenerative potential in severely infected tissue, simultaneous angiogenic and 30 antibacterial biomaterials are required, maximizing intrinsic angiogenesis by preserving 
1 angiogenic precursors against toxins from bacterial overgrowth.

Therapeutic ion-incorporated materials can have a pivotal role in addressing the

3 above issues. Metallic compound (e.g., $\mathrm{Ag}, \mathrm{Co}, \mathrm{Cu}, \mathrm{Ga}, \mathrm{Mn}$, or $\mathrm{Mg}$ )-loaded biomaterials

4 have been studied as promising antibacterial materials; sometimes, they are used with

5 antibiotic drugs, which decreases the dose of the antibiotics and consequent adverse

6 effects [19-23]. Among antibacterial metal compound, some metal (e.g. Co and $\mathrm{Cu}$ ) ions

7 are also well-known to promote angiogenesis via regulation of hypoxia-inducible (HIF)-1

$8 \alpha$, which can be synergistically activated by another angiogenic ion (i.e., Si ions) [24].

9 Thus, relaying the antibacterial and angiogenic activity into tissue regeneration process

10 can be realized through the ionic delivery approach.

11 Here, we strategize the dual delivery of $\mathrm{Si}$ and Co ions to reap up the dual-

12 functioning (pro-angiogenic and antibacterial functions). We design ion-doped glass

13 microparticles by a sol-gel method that can deliver therapeutic ions ( $\mathrm{Si}$ and Co ions)

14 sustainably at therapeutic dose. While the $\mathrm{Si}$ ions released from the glass chemistry at a

15 therapeutically relevant level, known to stimulate angiogenesis $[25,26]$, the Co ions have

16 also been implicated in stimulating angiogenesis [27,28]. Moreover, Co ions have been

17 shown to have antibacterial activity, penetrating the bacterial wall of the microorganisms

18 and inhibiting bacterial survivability and, thus, preserving angiogenic precursors for

19 blood vessel formation [29,30]. The effects of the delivered ions on angiogenic behaviors

20 are investigated in terms of polarization, migration, and tubular networking of endothelial

21 cells in vitro as well as neo-blood vessel formation in vivo. In parallel, antibacterial

22 effects and endothelial cells' survivability are investigated using a cell-bacteria co-culture

23 system. This approach, as the first report on the ionic-delivery of biomaterials for dual-

24 functions, is envisaged to shed light on the development of a new class of therapeutic

25 biomaterials for infected tissue regeneration. 


\section{Materials and methods}

2.1 Preparation of the microcarriers

3 Tetraethyl orthosilicate (TEOS, Sigma-Aldrich,, St. Louis, MO, USA) was used to form a

4 silica network, and $0.1 \mathrm{M} \mathrm{HCl}$ was added to $10 \mathrm{ml}$ of TEOS. Cobalt chloride (4\%, Sigma-

5 Aldrich) was separately diluted in deionized water. Cobalt chloride solution (at four

6 different concentrations $0,1,2.5$, and $5 \mathrm{wt} \%$ ) was added to the silica sol, which was

7 adjusted to $\mathrm{pH}$ values between 5.0-5.5 by the addition of $0.08 \mathrm{M}$ ammonium hydroxide

8 (Sigma-Aldrich). Cobalt-incorporated microcarriers were collected after stabilization,

9 washed several times with ethanol and left overnight to dry. Then, $0 \%, 1 \%, 2.5 \%$, and $5 \%$

10 cobalt incorporated in silica microcarriers were coded as $\mathrm{Co}$, Co1, Co2.5, and Co5.0.

11 But, Co5.0 was excluded in further characterization due to their failure of 12 cytocompatibility by cell viability test.

\subsection{Microcarrier characterization and ion release profile}

15 Scanning electron microscopy (SEM; JEOL JSM 6510, Tokyo, Japan) was used to 16 observe the homogenous distribution of microspheres and mesoporous morphology of the 17 surface. Cobalt ion incorporation was identified by the EDS method. Mesoporous 18 characterization was quantified using the Quadrasorb SI automated surface area and pore 19 size analyzer (Quadrasorb SI, Quantachrom instruments Ltd., Boynton Beach, FL, USA) 20 using $\mathrm{N}_{2}$ gas adsorption/desorption with the Brunauer-Emmet-Teller (BET) theory. The

21 total pore volume was determined from the adsorbed amount at maximum relative 22 pressure $(\mathrm{P} / \mathrm{P} 0)$.

23 Cobalt and silicon release from microcarriers was measured in $\alpha$-minimal essential 24 medium ( $\alpha$-MEM LM 008-01, Welgene, Gyeongsan-si, Korea) solution for up to 7 days $25 \quad(10 \mathrm{mg} / \mathrm{mL})$ at $37^{\circ} \mathrm{C}$. The samples were centrifuged, the supernatant was collected, and $2610 \mu \mathrm{L}$ of nitric acid was added to the supernatant to inhibit bacteria and free any bound 27 cobalt and silicon prior to measurement. Inductively coupled plasma atomic emission 28 spectroscopy (ICP-AES, OPTIMA 4300 DV, Perkin-Elmer, Waltham, MA, USA) was 29 used for detection. $5 \mathrm{wt} \%$ microsphere group was excluded in this characterizing tests 30 due to their failure of cytocompatibility by screening cell viability test. 
2 First, $2.0 \times 10^{4}$ human umbilical vein endothelial cells (HUVECs, cat\# PCS-100-010,

3 ATCC, Manassas, VA, USA) at passages 4-5 were used to test cell compatibility for up to

4 three days. Vascular cell basal medium (cat\# PCS-100-030, ATCC) supplemented with

5 endothelial cell growth kit-VEGF (cat\# PCS-100-041, ATCC) was used as endothelial

6 cell medium. Microcarriers were indirectly placed on the top of the well inserts (10

$7 \mathrm{mg} / \mathrm{mL}$ ), and cells were cultured on the bottom of a 24 well plate. At day 3, $100 \mu \mathrm{l}$ of

8 CCK-8 (cell counting kit-8, Dojindo Molecular Technologies Inc, Rockville, MD, USA)

9 solution was added into each well and then incubated at $37^{\circ} \mathrm{C}$ for $2 \mathrm{~h}$ according to the

10 manufacturer's instructions. The supernatant was collected, and its absorbance was

11 measured at $450 \mathrm{~nm}$ using a microplate reader (SpectraMax M2e, Molecular Devices,

12 Sunnyvale, CA, USA). This test was used for screening experimental groups for previous

13 physico-chemical characterization (section 2.2) and further biological study, excluding 5

14 wt \% microsphere group.

\subsection{Quantitative real-time polymerase chain reaction ( $q R T-P C R$ )}

17 Pro-angiogenic gene expression was quantified by qRT-PCR. HUVECs $\left(1.0 \times 10^{5}\right)$ were 18 indirectly treated with microcarriers for $24 \mathrm{~h}$ by using transwell insert $(10 \mathrm{mg} / \mathrm{mL})$. After 19 removing the insert, the cells on the bottom were washed with cold phosphate-buffered 20 saline (PBS), and total RNA was extracted by centrifuging and filter system according to 21 the manufacturer`s instructions (GeneAll, Ribospin, Seoul, Korea). After purified mRNA

22 was quantified (Nanodrop 2000 spectrophotometer; Thermo Scientific, Waltham, MA,

23 USA), cDNA was synthesized by reverse-transcribing $1 \mu \mathrm{g}$ of mRNA using the High-

24 Capacity RNA-to-cDNA Kit (Thermofisher) and carried out by a thermal cycle (Model

25 2720, Applied Biosystems, Foster City, CA, USA). PCR amplification was performed 26 using the SYBR green qPCR SuperMix reagent (Invitrogen) and analysed by a real-time 27 PCR system (7300-RT-PCR; Applied Biosystems, Foster City, CA, USA) according to 28 the manufacturers' instructions [31]. GAPDH was used to normalize VEGF and HIF1- $\alpha$ 29 genes with respect to control according to the previous literatures [32] using $2^{\wedge}(-\Delta \Delta \mathrm{Ct})$ 30 value by StepOne (v2.3, Applied Biosystems, Foster City, CA, USA). Furthermore, 31 different concentrations of cobalt chloride $(6,12$, and $18 \mathrm{ppm})$ were used to study VEGF, 
1 HIF 1- $\alpha$, and KDR gene expression to compare the effects of the free form of cobalt ions

2 with the effects of the cobalt ions in the microcarriers. Cobalt chloride was dissolved in

3 distilled water and added to the transwell plate with silica microcarriers, which were then

4 used for the experiment.

\subsection{Endothelial cell polarization study}

7 HUVECs $\left(5.0 \times 10^{3}\right)$ were seeded on 24 well plates for $4 \mathrm{~h}$ for the cells to attach to the 8 plate, and then microcarriers with transwell inserts $(10 \mathrm{mg} / \mathrm{mL})$ were placed there for $1 \mathrm{~h}$.

9 After removing transwell inserts, cells were fixed and stained with 4',6-diamidino-2-

10 phenylindole (DAPI, nucleus) and phalloidin (cytoskeleton). Each group of images was

11 captured by confocal laser scanning microscopy (CLSM, LSM 700, Carl Zeiss,

12 Oberkochen, Germany). Polarized distance was identified by measuring the distance

13 between the centres of mass and the nucleus based on the captured images using Image $\mathbf{J}$

14 (ver. 1.52a, NIH, USA).

\subsection{Ion attraction study}

17 Microcarriers were positioned in the bottom of a 24 well plate $(10 \mathrm{mg} / \mathrm{mL})$, and $5.0 \times 10^{3}$

18 cells were seeded on the $8 \mu \mathrm{m}$ pore-sized transwell insert for $4 \mathrm{~h}$. Chemoattraction was

19 examined after $4 \mathrm{~h}$ by staining the nucleus of the cells above the insert after scratching

20 the bottom side. Attracted cell numbers were counted using ImageJ software and

21 converted into a percentage.

\section{$23 \quad 2.7$ Endothelial cell migration}

24 Mitomycin B (Sigma) was used as an inhibitor of proliferation and mixed with non25 supplemented HUVEC media. Moreover, $1.0 \times 10^{5}$ cells were seeded initially, and $24 \mathrm{~h}$ 26 was waited for the cells to achieve confluence; mitomycin B was added to cells for $2 \mathrm{~h}$. A

$27200 \mu \mathrm{L}$ tip was used to scratch the confluent cell layer to observe cell migration. 28 Microcarriers were placed on transwell insert plates $(10 \mathrm{mg} / \mathrm{mL})$ and transferred to the 29 scratched cells. Images were taken at $6 \mathrm{~h}, 12 \mathrm{~h}$, and $24 \mathrm{~h}$ by light microscopy (IX-71; 30 Olympus, Tokyo, Japan). 
2.8 Tubular network and formation ability

3 Tubulogenesis was determined using a Matrigel (356234, Corning, NY, USA) matrix.

4 The Matrigel was prepared and coated onto 24-well plates according to the 5 manufacturer's instructions. HUVECs $\left(3.0 \times 10^{4}\right)$ were seeded onto the Matrigel, and 6 microcarriers $(10 \mathrm{mg} / \mathrm{mL})$ were delivered with the insert. Cells were photographed at 7 each time point ( $6 \mathrm{~h}$ and $12 \mathrm{~h}$ ) using light microscopy (IX-71; Olympus). Three samples

8 were selected in each group, and random images were analyzed for the measurement of

9 the number of branch points (nodes), mesh-like circles (circles), and total tubule length.

2.9 Endothelial cells culturing on Matrigel-coated microcarrier

12 Microcarriers were covered by Matrigel to study cell adhesion and spreading. First,

13 Matrigel was diluted in $\alpha$-MEM media, and microcarriers were soaked in the diluted

14 Matrigel solution at $4^{\circ} \mathrm{C}$ for an hour on a shaker to obtain a homogenous coating. Next,

15 Matrigel-coated microcarriers were collected and incubated at $37^{\circ} \mathrm{C}$ for $1 \mathrm{~h}$ to complete

16 the gelation of the Matrigel. After the Matrigel-coated the microcarriers, $5.0 \times 10^{4}$ cells

17 were seeded directly onto the microcarriers and cultured for $6 \mathrm{~h}$ for the observation of

18 cell attachment. Cell adhesion and spreading were observed by SEM and CLSM using

19 the z-stack mode.

202.10 Angiogenesis in chick chorioallantoic membrane (CAM) model

21 Fertilized chicken embryos were pre-incubated at $37^{\circ} \mathrm{C}$ for 3 days under $60 \%$ humidity.

22 At day 3, albumen was aspirated and returned for incubation until day 7. No-treatment,

$23 \mathrm{Co} 0$ and $\mathrm{Co} 2.5$ groups were selected to study angiogenesis in the CAM model. Ten

24 milligrams of microcarriers was placed on the chick membrane surface on day 7 , and the

25 samples were transferred to the rotating incubator. At day 11, the chick membrane was

26 collected and fixed by neutralized buffered formalin for $24 \mathrm{~h}$. Membranes were dried and

27 visualized by Digital SLR camera (EOS 1000D, Canon, Tokyo, Japan). Tubule length,

28 size, and the total junction of the vessel were further analyzed by AngioQuant software

29 (Version 1.33, Mathwork Inc, Houston, TX, USA). 
1 Antibacterial tests were performed using two species of bacteria, Escherichia coli (E.

2 coli, ATCC 25922) and Streptococcus aureus (S. aureus, ATCC 25923), representing 3 gram-negative and gram-positive species, respectively. Bacteria $\left(1 \times 10^{7} / \mathrm{mL}\right)$ in the $\log$

4 phase of growth were cultured with $10 \mathrm{mg}$ of microcarriers or different concentrations of $5 \mathrm{CoCl}_{2}$ solution in 24-well plates with inserts. For positive or negative control, each 6 bacteria strain was cultured with vancomycin disk (30 $\mu \mathrm{g}$, Thermo fisher, Waltham, MA, 7 USA) or without any extrinsic biomaterials or chemicals respectively for further study.

8 After bacterial species were cultured for $4 \mathrm{~h}, 10 \%$ PrestoBlue (Molecular probes,

9 Invitrogen, Waltham, USA) was added, and culturing continued for another $1 \mathrm{~h}$. The

10 liquid $(100 \mu \mathrm{L})$ from each well $(\mathrm{n}=5)$ was transferred to each well of 96-well plates, and

11 the absorbance at $570 \mathrm{~nm}$ was measured using a microplate reader (SpectraMax M2e)

12 and then normalized to the absorbance at $600 \mathrm{~nm}$. Previously, along with the PrestoBlue 13 assay, colony-forming units (CFUs) from serially diluted bacterial species were counted

14 to confirm the correlation between the normalized absorbance in the PrestoBlue assay 15 and the microbial CFU numbers [27.28]. The assays were independently performed in 16 triplicate.

17 The Live/Dead kit assay (Thermo fisher) was used to visualize bacterial survivability 18 according to the manufacturer's protocols [23]. Briefly, bacteria $\left(10^{7} / \mathrm{ml}\right)$ with

19 microcarriers $(10 \mathrm{mg})$ were incubated for $4 \mathrm{~h}$ and stained with Syto-9 and propidium 20 iodide for direct visualization. To remove the autofluorescence backgrounds of 21 microcarriers and bacterial media, centrifugation (10000 rpm, $3 \mathrm{~min}$ ) was used for

22 collecting bacteria species. The supernatant was discarded, and PBS $(1 \mathrm{ml})$ with the 23 above two fluorescent dyes was added to stain bacteria. Green fluorescence represents 24 intact live species, and red represents dead species.

\subsection{Endothelial cell and bacteria co-culture}

27 Co-culture of HUVECs and E. coli was performed based on modified protocols, indicated 28 in other literatures [33-35]. After HUVECs $\left(2 \times 10^{4} / 100 \mu \mathrm{L}\right)$ was seeded on the each well 29 (96 well plate) and cultured for $24 \mathrm{~h}, 10 \mu \mathrm{L}$ of $E$. coli $\left(1 \times 10^{7}\right.$ or $\left.1 \times 10^{6} / \mathrm{mL}\right)$ in the log 
1 phase of growth was added with $100 \mu \mathrm{L}$ of extraction from microcarriers in HUVECs'

2 media $(10 \mathrm{mg} / \mathrm{mL})$ immersed for $24 \mathrm{~h}$ at $37^{\circ} \mathrm{C}$. After $6 \mathrm{~h}$ of co-culturing, live and dead

3 (Thermo fisher, Waltham, MA, USA) or VE-cadherin staining (1:50, sc-6458, Santa cruz

4 biotechnology, Dallas, TX, USA) was performed $(n=3)$. Culturing HUVECs with

5 extraction or HUVECs' media without bacteria contamination was used as a control. Live

6 and dead cells per image were counted from randomly selected five images in each well

7 and averaged. Fluorescence of VE-cadherin normalized to control was analyzed from

8 randomly selected five images in each well by Image $\mathrm{J}(\mathrm{NIH})$.

9

$10 \quad 2.13$ Statistics

11 Statistical analysis was performed with a one-way analysis of variance (ANOVA) with

12 the Tukey honest significant differences test as a post hoc test (IBM SPSS Statistics

13 v23.0; IBM Corp) ( $\mathrm{P}=0.05)$. Normal distribution test was performed by Shapiro-

14 Wilk test.

15

16 


\section{Results and discussion}

\subsection{Microcarrier characterization and ion release}

4 The doping of Co into Si-based microspheres was aimed to achieve the synergistic effect

5 of released $\mathrm{Co}^{2+}$ and $\mathrm{Si}$ ions on angiogenesis as well as the antibacterial effect of $\mathrm{Co}^{2+}$. After initial screening test, $5 \mathrm{wt} \%$ microsphere was excluded for further study, which are shown in detail below. Two different concentrations of Co (1 and $2.5 \mathrm{wt} \%$ ) were evenly

8 well doped into the Si-microsphere, as confirmed by EDS results (Supplementary data.1). Comparably sized microspheres $(200 \sim 350 \mu \mathrm{m})$ with similar mesoporous

10 structures $(2-3 \mathrm{~nm})$ (Fig. 1c) and high surface areas $\left(450 \sim 620 \mathrm{~m}^{2} / \mathrm{g}\right)$ (as detected by BET 11 analysis) (Fig. 1b) were successfully produced by the sol-gel method. Doping of Co to

12 the Si microspheres affected the structure of the microsphere to a limited extent except 13 glass amorphous network (Supplementary data.1); it slightly increased the pore size and 14 decreased the surface area without significant change of the total diameter, their 15 distribution and amorphous structure along with the results from amorphous glass 16 structure with a network modifier, enlarging 3D space in molecular level $[1,36]$.

The $\mathrm{Si}^{4+}$ and $\mathrm{Co}^{2+}$ ions released in $\alpha$-MEM were measured using ICP-AES for up

18 to 3 days (Fig. 1c). The $\mathrm{Co}^{2+}$ ions were released only from the $1 \%$ and $2.5 \%$ groups, as 19 anticipated, in an initial burst release $(\sim 4 \mathrm{~h})$ and highly sustained manner after that point $20\left(0 \%\right.$ and $2.5 \%$ are representatively shown). In the $2.5 \%$ group, $\mathrm{Co}^{2+}$ ions were released 21 rather rapidly for up to $4 \mathrm{~h}(\sim 9 \mathrm{ppm})$ and then continuously for up to 7 days ( $\sim 15 \mathrm{ppm})$; 22 thus the daily release in a week was $\sim 1-2$ ppm (per day). Loosely bound cobalt in the 23 silica network as a modifier initially released in ionic form, and then cobalt in the inner 24 part of network started to release in a sustained manner after that, accelerated by 25 mesoporous structures of microspheres to approach the therapeutic concentration of ions. 26 In a previous study, more than $2 \mathrm{ppm}$ of $\mathrm{Co}^{2+}$ ion release was shown to be toxic to the 27 surrounding tissues [37]. Moreover, silicate ions were released at 2 3 ppm per day, which 28 was reported to be nontoxic and in a therapeutic range $[25,38]$.

29 To investigate cytocompatibility of microspheres in accelerated condition, 30 enabling exclusion of toxic experimental group(s) for further biological studies, different 31 concentration of microspheres $(10 \sim 100 \mathrm{mg})$ were cultured indirectly (using a transwell 
1 insert) with relatively lower HUVECs numbers $\left(2.0 \times 10^{4} / \mathrm{mL}\right.$ of $1 \mathrm{~mL}$ in 24 well) for 3

2 days, exhibiting no significant cellular toxicity in all groups except $5 \mathrm{wt} \%(\sim 30 \%)$

3 compared to control when used at $10 \mathrm{mg} / \mathrm{mL}$ of microsphere concentration. Thus, 0,1 ,

4 and $2.5 \mathrm{wt} \%$ at $10 \mathrm{mg} / \mathrm{mL}$ of microsphere concentration are selected for the following in

5 vitro experiments (Supplementary data.2).

\subsection{Cobalt- and silicate-ion synergism in angiogenesis-related gene expression}

8 As a biological assay in detail, firstly, the synergistic role of the Co and $\mathrm{Si}$ ions in 9 angiogenesis was investigated by the expression of angiogenic genes, quantified by qRT-

10 PCR. VEGF, a major growth factor for angiogenesis, is well known to be upregulated by

11 the activation of HIF1- $\alpha$ [39-41]. According to the literature, $\mathrm{Co}^{2+}$ ions can stimulate

12 hypoxic conditions via direct binding to $\mathrm{HIF} 1-\alpha$ and stabilizing it, while $\mathrm{Si}^{4+}$ has been

13 reported to promote HIF1- $\alpha$ expression by degrading the PHD2 enzyme [7], leading to

14 the possibility of synergistically accelerating angiogenesis-related gene expression

$15[27,42]$. The Co2.5 group showed significantly higher expression of pro-angiogenic

16 genes including VEGF, KDR and HIF $1-\alpha$ than the $\mathrm{Co} 0$ and $\mathrm{Co} 1$ groups, while $\mathrm{Co} 0$ also

17 showed higher gene expression than the control, which means that $\mathrm{Co}^{2+}$ and $\mathrm{Si}$ ions

18 synergistically promoted the expression of VEGF and KDR via upregulation of HIF1- $\alpha$

19 (Fig. 2). To confirm the role of Co ions, the free form of $\mathrm{Co}^{2+}$ ions $(6,12$ and $18 \mathrm{ppm})$

20 was used to supplement $\mathrm{Co} 0$; these concentrations are around the range of the

21 concentrations of Co ions released into same amount media from microspheres (10

$22 \mathrm{mg} / \mathrm{mL}$ ) for $24 \mathrm{~h}$ (Fig. 1c), and gene expression occurred in the same manner. All Co ion-

23 treated groups showed a significant increase in gene expression, especially $12 \mathrm{ppm}$ Co

24 ions, which is the similar concentration of Co ions released into media in $24 \mathrm{~h}$ from the

$25 \mathrm{Co} 2.5(\sim 12 \mathrm{ppm})$. Because the Co2.5 group showed the greatest increase in angiogenic

26 gene expression, $12 \mathrm{ppm}$ Co ions was the optimal concentration for synergetic effects,

27 matching results from other endothelial cells such as HMEC-1 and umbilical cord blood-

28 derived CD133(+) cells $[28,43]$.

\subsection{Promotion of endothelial cell functions in vitro}

31 The polarization of endothelial cells initiates endothelial cell migration for angiogenesis, 
1 thus considered as the initial cell behavior for the formation of neo-blood vessels and mature vasculature $[44,45]$. Here the cellular polarization was determined in endothelial 3 cells by measuring the shift in the cellular nucleus from the centre of mass at a single cell 4 level (Fig. 3a). For single cell analysis, the twenty fold decreased cell number compared 5 to that for gene expression study was seeded for $4 \mathrm{~h}$ and further co-cultured for $1 \mathrm{~h}$ with $610 \mathrm{mg}$ of microspheres. Compared with the control group (w/o microspheres) all 7 microsphere groups significantly promoted cell polarization, and the Co-releasing groups 8 (Co1 and Co2.5) synergistically increased the cell polarization with respect to Co0. The 9 cell homing behavior was then carried out to clarify the chemo (ion) attractant efficacy of 10 the released $\mathrm{Co}^{2+}$ ion, an essential characteristic during angiogenic process for making 11 tubular formation. After the small number of cells $\left(5 \times 10^{3}\right)$ initially placed in a transwell 12 insert for $4 \mathrm{~h}$ then moved toward the ion-releasing microspheres in the 24 well bottom 13 place, ion attracted cell numbers from insert top surface to microspheres in 24 well 14 bottom were counted. Results showed that the number of cells migrated down increased 15 in the order: control $(\sim 5 \%)<\mathrm{Co} 0$ and $\mathrm{Co} 1(\sim 60 \%)<\mathrm{Co} 2.5(\sim 85 \%)$ (Fig. 3b), which is 16 similar to what was observed in cell polarization.

17 Next, the cell migration assay involving a scratch model was then performed to 18 determine cellular motility (Fig. 4). In particular, HUVECs were treated with mitomycin 19 B to inhibit proliferation. The cellular gathering into a scratched gap was captured at 20 different time points $(6,12$, and $24 \mathrm{~h}$ ) to count the migrated cells (Fig. 4a). The migrated 21 cell number increased with time $(6 \mathrm{~h}<12 \mathrm{~h}<24 \mathrm{~h})$ and the cell number became 22 significantly different among groups with time (w/o Contr. $<\mathrm{Co} 0<\mathrm{Co} 1<\mathrm{Co} 2.5$, Fig. 23 4b). demonstrate in vitro angiogenesis on biomimetic soft extracellular matrix condition. The 26 greater vessel-like formation was found in the Co2.5 group than in the control and $\mathrm{Co} 0$ 27 groups at each time point based on the image and quantitative analysis of node and circle 28 numbers ( 6 and 12 h, $\mathrm{P}<0.05$, Fig. $5 \mathbf{a}$ and $\mathbf{b})$. After confirming the role of ions released 29 from the microsphere, the endothelial cells were directly cultured on the microspheres 30 after coated with Matrigel. The F-actin stained and electron microscopic images indicated 31 that endothelial cells adhered and elongated much better on the surface of the co-delivery 
1 microcarriers (Fig. $\mathbf{5 c}$ ). Taken the results together, the synergetic stimulation of in vitro

2 endothelial cell behaviors such as initial polarization poising, cell homing by ion

3 attraction, cell migration and tubular formation were demonstrated by the simultaneous

4 release of $\mathrm{Co}^{2+}$ and $\mathrm{Si}^{4+}$ ions from the microcarriers.

\subsection{In vivo neo-vessel formation with microcarriers}

7 Lastly, a CAM assay was performed to evaluate new blood vessel formation in the in 8 vivo condition (Fig. 6). Microspheres of $10 \mathrm{mg}$ were implanted for 4 days in the model, 9 and the neo-vessel formation was imaged and analyzed. Optical micrographs showed a 10 clear difference in blood vessel formation among the control, $\mathrm{Co} 0$ and $\mathrm{Co} 2.5$ groups, with 11 noticeable observation of a number of neo-vessels branched from old vessels in the Co2.5 12 group. When the neo-vessel indices were quantified, the Co2.5 group exhibited 13 significantly greater total vessel length, size, and junction ( $\sim 3$ times) than the $\mathrm{Co} 0$ and 14 control group, demonstrating that $\mathrm{Co}^{2+}$ and $\mathrm{Si}^{4+}$ ions synergistically promoted the 15 formation of vascular networks from existing vessels in in vivo systems.

16 Previously, we showed that the Si ion-releasing microspheres used at relatively 17 high amount $(100 \mathrm{mg})$ had pro-angiogenic effects ( 1.5 times higher than control) in 18 CAM assay [7]; strikingly, here we noticed that the $\mathrm{Co} / \mathrm{Si}$-releasing microspheres 19 administered at only $10 \mathrm{mg}$ (1/10 of the previous study) stimulated the neo-vessel 20 formation of control by as high as $\sim 3$ times, and this level is comparable to that when 21 VEGF was co-delivered with $\mathrm{Si}$ ion in the previous work. This fact suggests that the 22 synergistic action of co-delivered ions might be effective in such a way that can replace 23 the function of angiogenic growth factor(s), and more ambitiously, open a new strategy of 24 growth factor-free therapeutic delivery system, which yet needs further comparative 25 studies.

\subsection{Antibacterial potential of the microcarriers}

28 To examine the antibacterial effects of the $\mathrm{Co} / \mathrm{Si}$ ion-delivering microspheres, two 29 representative bacteria, E. coli (gram $+\mathrm{ve}$ ) and S. aureus (gram -ve), that are prevalent 30 bacterial strains in damaged tissues, were selected. The results showed that bacterial 31 survivability was inhibited to almost below $50 \%$ in the Co2.5 group, demonstrating the 
1 effectiveness of the $\mathrm{Co}^{2+}$ ions released from microspheres (Fig. 7a). The use of free $\mathrm{Co}^{2+}$

2 ions $(6 \sim 18 \mathrm{ppm})$ from $\mathrm{CoCl}_{2}$ similarly inhibited the bacterial viability. As the free $\mathrm{Co}^{2+}$

3 ions have been used as positive control for strong antibacterial agent, the microspheres

4 are considered to hold excellent antibacterial activity [29,30,46].

$5 \quad$ The live/dead staining of bacteria clearly showed the damage of cell membrane

6 (Fig. 7b). More bacteria cells were damaged (red) (fewer live cells, in green) in the Co1

7 and $\mathrm{Co} 2.5$ groups than in the $\mathrm{Co} 0$ group. Because of the autofluorescence of 8 microcarriers, detecting red signals in direct contact condition was difficult.

9 Supplementary data 3 shows more bacteria alive appeared in $\mathrm{Co} 0$ group compared to

$10 \mathrm{G} 1$ and G2.5 groups. Taken from antibacterial results, the $\mathrm{Co}^{2+}$ ions released from

11 microcarriers were effective enough to inhibit bacterial survivability.

\section{$13 \quad 3.5$ Salvage of endothelial cells from bacteria contamination}

14 To further examine the multi-functional effects of the $\mathrm{Co} / \mathrm{Si}$-delivery microcarriers in a 15 more clinically relevant pathogenic condition, HUVECs were intentionally contaminated

16 with a model strain (E. coli), one of the prevalent bacterial strains found in tissue 17 infection, and then cultured with the ionic extracts of microcarriers (Fig. 8a). In case of 18 regeneration of infected tissue, the body naturally reacts to disease-causing bacteria by 19 increasing local blood flow along with the stimulated angiogenesis intrinsically and 20 extrinsically for rapidly recruiting immune cells to destroy/uptake the bacteria [17]. Thus, 21 preserving proangiogenic cells in the infected site and forming blood vessel together with 22 angiogenic precursors collected from surrounding tissue are suggested as a promising 23 therapeutic strategy, especially for severely infected tissue [18]. Because, the delay of 24 clearance of pathogens and consequent lack of proangiogenic cells via accumulated 25 toxins deteriorates proper angiogenesis and further tissue repair/regeneration in infected 26 site. Therefore, simultaneous angiogenic and antibacterial biomaterials are required for 27 preserving angiogenic precursors against toxins from bacterial overgrowth and 28 accelerating angiogenesis. The co-culture of bacteria/mammalian cells has recently been

29 employed to mimic the clinically relevant bacterial infection-associated tissue 30 environment [33-35]. When mammalian cells are in contact with certain number of 31 bacterial strain, they lose viability and biological functionality due to micro-organism 
1 induced toxins (through cell-bacteria direct interaction or paracrine signaling) [47].

2 Therefore, killing bacteria species or scavenging their dead body that can act micro-

3 organism associated molecular pattern and cause severe inflammation and malfunction of

4 host cells is considered an effective strategy to inhibit bacterial growth and ultimately to

5 regain tissue regenerative capacity [48]. In this study, exterminating model bacteria strain

6 was aimed to preserve the survivability and functionality of endothelial cells. From the

7 co-culture test, the G2.5 group enabled more persisting endothelial cell viability than the

8 control and G0 group under the bacterial contaminations (Fig. 8b). Of note, the VE-

9 cadherin was expressed at significantly higher levels in G2.5 group than others, implying

10 the endothelial cells with G2.5 have the potential to form tubular networks of blood

11 vessels as this VE-cadherin is known as an essential anatomical structure of endothelial

12 cells that can form blood vessels. While the potential to preserving endothelial

13 survivability was decreased with increasing the bacteria number, the role of $\mathrm{Co} / \mathrm{Si}$ -

14 releasing microspheres was evident across the conditions investigated.

15 Taken the bacterial studies together, the Co/Si-releasing microcarriers were

16 proven to inhibit bacterial growth either in direct or indirect contact (monoculture) and

17 even to salvage the endothelial cell survivability and possible functional activity from the

18 bacterial contamination (co-cultured). Although this study could demonstrate some in

19 vitro efficacy of the microcarriers, with its limited in vitro conditions, the extrapolation to

20 clinical situations may be ambitious, warranting more in vivo studies in infected tissue

21 models.

\section{4. Conclusion}

24 Multifunctional $\mathrm{Co} / \mathrm{Si}$-containing microcarriers were designed to deliver dual therapeutic

25 ions that can ultimately promote angiogenesis while inhibiting bacterial activity. The

26 results demonstrated synergistic stimulation of endothelial cell functions such as

27 angiogenic gene expression, polarization, migration and tubular formation, through the

$28 \mathrm{Co}^{2+}$ and $\mathrm{Si}^{4+}$ ions co-delivered from microspheres. Moreover, the viability of both gram-

29 positive and gram-negative model bacterial strains was strongly prohibited, and the

30 survivability and cell-cell junction of endothelial cells were significantly salvaged under

31 bactericidal conditions made in a co-culture model. Although more clinically relevant in 
1 vivo studies are required further, this study highlights the effective roles of multiple ions

2 co-delivered from biomaterials played in antibacterial-proangiogenic actions and suggests

3 possible applications in the infected tissues that require both inhibition of bacterial

4 activity and vascularized tissue regeneration.

\section{Acknowledgement}

7 This work was supported by the National Research Foundation of Korea (NRF) grant

8 funded by the Korean government (MSIP; Ministry of Science, ICT \& Future Planning,

9 2018R1A2B3003446) and Global Research Development Center Program

10 (2018K1A4A3A01064257).

\section{Statement}

13 The researcher claims no conflicts of interest

15 Appendix A. Supplementary data

17 Supplementary data 1. (a) Inner and outer part of microsphere was visualized by SEM 18 and (b) their composition was characterized by $\operatorname{EDS}(n=3)$. Inner structure was revealed 19 after being fractured by compressive force. Dotted line in (a) was analysed by EDS and 20 results were shown in (b). Equal composition is revealed between inner and outer part of 21 each microsphere (1 or 2.5\%). (c) XRD results present amorphous structure of the silica 22 network and there is no influence of the glass network due to lower concentration of 23 cobalt.

24 Supplementary data 2. Different amounts of microcarriers were evaluated for their 25 effects on cell proliferation by CCK assay ( $* \mathrm{P}<0.05 \& * * \mathrm{P}<0.01, \mathrm{n}=5)$. Ten milligrams 26 of microcarriers was selected for concentration used in further biological assay and 5\% 27 was excluded among experimental groups.

28 Supplementary data 3. Live and dead staining of bacteria using direct co-culture 
1 conditions with microcarriers. Fewer live bacteria species were detected in the area

2 surrounding the $2.5 \%$ microcarriers for both the E. coli and $S$. aureus species $(\mathrm{n}=3)$.

3 Representative images with moving bacteria are shown.

4 Supplementary table 1. Detail of in vitro experiment

5

6 


\section{References}

2 [1] G.J. Owens, R.K. Singh, F. Foroutan, M. Alqaysi, C.M. Han, C. Mahapatra, H.W.

3 Kim, J.C. Knowles, Sol-gel based materials for biomedical applications, Prog.

$4 \quad$ Mater. Sci. 77 (2016) 1-79. doi:10.1016/J.PMATSCI.2015.12.001.

5 [2] C.A. Cezar, D.J. Mooney, Biomaterial-based delivery for skeletal muscle repair,

6 Adv. Drug Deliv. Rev. 84 (2015) 188-197. doi:10.1016/J.ADDR.2014.09.008.

7 [3] P.J.M. Smeets, K.R. Cho, R.G.E. Kempen, N.A.J.M. Sommerdijk, J.J. De Yoreo,

8 Calcium carbonate nucleation driven by ion binding in a biomimetic matrix

9 revealed by in situ electron microscopy, Nat. Mater. 14 (2015) 394-399.

10 doi:10.1038/nmat4193.

11 [4] J.H. Lee, N. Mandakhbayar, A. El-Fiqi, H.W. Kim, Intracellular co-delivery of Sr

12 ion and phenamil drug through mesoporous bioglass nanocarriers synergizes BMP

13 signaling and tissue mineralization, Acta Biomater. 60 (2017) 93-108.

14 doi:10.1016/j.actbio.2017.07.021.

15 [5] J.H. Lee, A. El-Fiqi, N. Mandakhbayar, H.H. Lee, H.W. Kim, Drug/ion co-

16 delivery multi-functional nanocarrier to regenerate infected tissue defect,

17 Biomaterials. 142 (2017) 62-76. doi:10.1016/j.biomaterials.2017.07.014.

18 [6] A. Hoppe, N.S. Güldal, A.R. Boccaccini, A review of the biological response to

19 ionic dissolution products from bioactive glasses and glass-ceramics, Biomaterials.

2032 (2011) 2757-2774. doi:10.1016/j.biomaterials.2011.01.004.

21 [7] K. Dashnyam, G.-Z. Jin, J.-H. Kim, R. Perez, J.-H. Jang, H.-W. Kim, Promoting

22 angiogenesis with mesoporous microcarriers through a synergistic action of

23 delivered silicon ion and VEGF, Biomaterials. 116 (2017) 145-157.

24 doi:10.1016/j.biomaterials.2016.11.053.

25 [8] S.J. Seo, M. Chen, H. Wang, M.S. Kang, K.W. Leong, H.W. Kim, Extra- and

26 intra-cellular fate of nanocarriers under dynamic interactions with biology, Nano

27 Today. 14 (2017) 84-99. doi:10.1016/j.nantod.2017.04.011.

28 [9] R.A. Perez, S.J. Seo, J.E. Won, E.J. Lee, J.H. Jang, J.C. Knowles, H.W. Kim,

Therapeutically relevant aspects in bone repair and regeneration, Mater. Today. 18

31 [10] C. Wu, J. Chang, Multifunctional mesoporous bioactive glasses for effective 
delivery of therapeutic ions and drug/growth factors, J. Control. Release. 193 (2014) 282-295. doi:10.1016/j.jconrel.2014.04.026.

[11] D.A. Kim, J.H. Lee, S.K. Jun, H.W. Kim, M. Eltohamy, H.H. Lee, Sol-gel-derived bioactive glass nanoparticle-incorporated glass ionomer cement with or without chitosan for enhanced mechanical and biomineralization properties, Dent. Mater. 33 (2017) 805-817. doi:10.1016/j.dental.2017.04.017.

[12] P. Benny, M. Raghunath, Making microenvironments: A look into incorporating macromolecular crowding into in vitro experiments, to generate biomimetic microenvironments which are capable of directing cell function for tissue engineering applications, J. Tissue Eng. 8 (2017) 204173141773046. doi:10.1177/2041731417730467.

[13] M. Karin, H. Clevers, Reparative inflammation takes charge of tissue regeneration, Nature. (2016). doi:10.1038/nature17039.

[14] B. Allegranzi, B. Zayed, P. Bischoff, N.Z. Kubilay, S. de Jonge, F. de Vries, S.M. Gomes, S. Gans, E.D. Wallert, X. Wu, M. Abbas, M.A. Boermeester, E.P. Dellinger, M. Egger, P. Gastmeier, X. Guirao, J. Ren, D. Pittet, J.S. Solomkin, WHO Guidelines Development Group, New WHO recommendations on intraoperative and postoperative measures for surgical site infection prevention: an evidence-based global perspective, Lancet Infect. Dis. 16 (2016) e288-e303. doi:10.1016/S1473-3099(16)30402-9.

[15] L.M. Baddour, Y.-M. Cha, W.R. Wilson, Infections of Cardiovascular Implantable Electronic Devices, N. Engl. J. Med. 367 (2012) 842-849. doi:10.1056/NEJMcp1107675.

[16] D.T. Huang, D.M. Yealy, M.R. Filbin, A.M. Brown, C.-C.H. Chang, Y. Doi, M.W. Donnino, J. Fine, M.J. Fine, M.A. Fischer, J.M. Holst, P.C. Hou, J.A. Kellum, F. Khan, M.C. Kurz, S. Lotfipour, F. LoVecchio, O.M. Peck-Palmer, F. Pike, H. Prunty, R.L. Sherwin, L. Southerland, T. Terndrup, L.A. Weissfeld, J. Yabes, D.C. Angus, Procalcitonin-Guided Use of Antibiotics for Lower Respiratory Tract Infection, N. Engl. J. Med. 379 (2018) 236-249. doi:10.1056/NEJMoa1802670.

[17] N. Osherov, R. Ben-Ami, Modulation of Host Angiogenesis as a Microbial Survival Strategy and Therapeutic Target, PLOS Pathog. 12 (2016) e1005479. 
doi:10.1371/journal.ppat.1005479.

[18] P. Carmeliet, Angiogenesis in life, disease and medicine, Nature. 438 (2005) 932 936. doi:10.1038/nature04478.

[19] M.T. Islam, R.M. Felfel, E.A. Abou Neel, D.M. Grant, I. Ahmed, K.M.Z. Hossain, Bioactive calcium phosphate-based glasses and ceramics and their biomedical applications: A review, J. Tissue Eng. 8 (2017) 204173141771917. doi: $10.1177 / 2041731417719170$.

[20] N. Sanpo, C.C. Berndt, J. Wang, Microstructural and antibacterial properties of zinc-substituted cobalt ferrite nanopowders synthesized by sol-gel methods, J. Appl. Phys. 112 (2012) 1-7. doi:10.1063/1.4761987.

[21] J. Parada, A.N.A.M. Atria, G. Wiese, E. Rivas, G. Corsini, Synthesis, Characterization and Antibacterial Activity of Cobalt ( Iii ) Complex With Phenanthroline and Maltose, J. Chil. Chem. Soc. 59 (2014) 2636-2639.

[22] H. Feng, G. Wang, W. Jin, X. Zhang, Y. Huang, A. Gao, H. Wu, G. Wu, P.K. Chu, Systematic Study of Inherent Antibacterial Properties of Magnesium-based Biomaterials, ACS Appl. Mater. Interfaces. 8 (2016) 9662-9673. doi:10.1021/acsami.6b02241.

[23] J.K. Jo, A. El-Fiqi, J.H. Lee, D.A. Kim, H.W. Kim, H.H. Lee, Rechargeable microbial anti-adhesive polymethyl methacrylate incorporating silver sulfadiazineloaded mesoporous silica nanocarriers, Dent. Mater. 33 (2017) e361-e372. doi:10.1016/J.DENTAL.2017.07.009.

[24] A. Malhotra, P. Habibovic, Calcium Phosphates and Angiogenesis: Implications and Advances for Bone Regeneration, Trends Biotechnol. 34 (2016) 983-992. doi:10.1016/j.tibtech.2016.07.005.

[25] K. Dashnyam, A. El-Fiqi, J.O. Buitrago, R.A. Perez, J.C. Knowles, H.-W. Kim, A mini review focused on the proangiogenic role of silicate ions released from silicon-containing biomaterials, J. Tissue Eng. 8 (2017) 204173141770733. doi:10.1177/2041731417707339.

[26] R.E. Gurlin, M.T. Keating, S. Li, J.R. Lakey, S. de Feraudy, B.S. Shergill, E.L. Botvinick, Vascularization and innervation of slits within polydimethylsiloxane sheets in the subcutaneous space of athymic nude mice, J. Tissue Eng. 8 (2017) 
204173141769164. doi:10.1177/2041731417691645.

[27] T. Tanaka, I. Kojima, T. Ohse, J.R. Ingelfinger, S. Adler, T. Fujita, M. Nangaku, Cobalt promotes angiogenesis via hypoxia-inducible factor and protects tubulointerstitium in the remnant kidney model, Lab. Investig. (2005). doi:10.1038/labinvest.3700328.

[28] A. Namiki, E. Brogi, M. Kearney, E.A. Kim, T. Wu, T. Couffinhal, L. Varticovski, J.M. Isner, Hypoxia induces vascular endothelial growth factor in cultured human endothelial cells, J Biol Chem. 270 (1995) 31189-95. doi:10.1074/jbc.270.52.31189.

[29] E.L. Chang, C. Simmers, D.A. Knight, Cobalt complexes as antiviral and antibacterial agents, Pharmaceuticals. 3 (2010) 1711-1728. doi:10.3390/ph3061711.

[30] M. Oves, M. Arshad, M.S. Khan, A.S. Ahmed, A. Azam, I.M.I. Ismail, Antimicrobial activity of cobalt doped zinc oxide nanoparticles: Targeting water borne bacteria, J. Saudi Chem. Soc. 19 (2015) 581-588. doi:10.1016/j.jscs.2015.05.003.

[31] J.H. Lee, H.H. Lee, H.W. Kim, J.W. Yu, K.N. Kim, K. Kim, Immunomodulatory/anti-inflammatory effect of ZOE-based dental materials., Dent. Mater. 33 (2017) e1-e12. doi:10.1016/j.dental.2016.09.012.

[32] S.K. Jun, S.A. Yang, Y.J. Kim, A. El-Fiqi, N. Mandakhbayar, D.-S. Kim, J. Roh, S. Sauro, H.W. Kim, J.H. Lee, H.H. Lee, Multi-functional nano-adhesive releasing therapeutic ions for MMP-deactivation and remineralization, Sci. Rep. 8 (2018) 5663. doi:10.1038/s41598-018-23939-6.

[33] D.S. Trentin, D.B. Silva, A.P. Frasson, O. Rzhepishevska, M. V. da Silva, E. de L. Pulcini, G. James, G. V. Soares, T. Tasca, M. Ramstedt, R.B. Giordani, N.P. Lopes, A.J. Macedo, Natural Green Coating Inhibits Adhesion of Clinically Important Bacteria, Sci. Rep. 5 (2015) 8287. doi:10.1038/srep08287.

[34] L. Goers, P. Freemont, K.M. Polizzi, Co-culture systems and technologies: taking synthetic biology to the next level., J. R. Soc. Interface. 11 (2014). doi:10.1098/rsif.2014.0065.

[35] S. Zaatreh, K. Wegner, M. Strauß, J. Pasold, W. Mittelmeier, A. Podbielski, B. Kreikemeyer, R. Bader, Co-Culture of S. epidermidis and Human Osteoblasts on 
Implant Surfaces: An Advanced In Vitro Model for Implant-Associated Infections, PLoS One. 11 (2016) e0151534. doi:10.1371/journal.pone.0151534.

[36] M.S. Kang, N.-H. Lee, R.K. Singh, N. Mandakhbayar, R.A. Perez, J.-H. Lee, H.W. Kim, Nanocements produced from mesoporous bioactive glass nanoparticles, Biomaterials. 162 (2018) 183-199. doi:10.1016/J.BIOMATERIALS.2018.02.005.

[37] Z.T. Birgani, N. Gharraee, A. Malhotra, C. a van Blitterswijk, P. Habibovic, Combinatorial incorporation of fluoride and cobalt ions into calcium phosphates to stimulate osteogenesis and angiogenesis, Biomed. Mater. 11 (2016) 015020. doi:10.1088/1748-6041/11/1/015020.

[38] D. Arcos, M. Vallet-Regí, Sol-gel silica-based biomaterials and bone tissue regeneration, Acta Biomater. 6 (2010) 2874-2888.

doi:10.1016/j.actbio.2010.02.012.

[39] S.J. Mandriota, M.S. Pepper, Vascular endothelial growth factor-induced in vitro angiogenesis and plasminogen activator expression are dependent on endogenous basic fibroblast growth factor., J. Cell Sci. 110 ( Pt 1 (1997) 2293-2302.

[40] R. Munoz-Chapuli, A.R. Quesada, M. Angel Medina, Angiogenesis and signal transduction in endothelial cells, Cell. Mol. Life Sci. 61 (2004) 2224-2243. doi:10.1007/s00018-004-4070-7.

[41] K.Y. Lee, M.C. Peters, D.J. Mooney, Comparison of vascular endothelial growth factor and basic fibroblast growth factor on angiogenesis in SCID mice, J. Control. Release. 87 (2003) 49-56. doi:10.1016/S0168-3659(02)00349-8.

[42] W. Fan, R. Crawford, Y. Xiao, Enhancing in vivo vascularized bone formation by cobalt chloride-treated bone marrow stromal cells in a tissue engineered periosteum model., Biomaterials. 31 (2010) 3580-9. doi:10.1016/j.biomaterials.2010.01.083.

[43] A. Hoppe, B. Jokic, D. Janackovic, T. Fey, P. Greil, S. Romeis, J. Schmidt, W. Peukert, J. Lao, E. Jallot, A.R. Boccaccini, Cobalt-Releasing 1393 Bioactive Glass-Derived Scaffolds for Bone Tissue Engineering Applications, ACS Appl. Mater. Interfaces. 6 (2014) 2865-2877.

[44] A. Shamloo, N. Ma, M.-M. Poo, L.L. Sohn, S.C. Heilshorn, Endothelial cell polarization and chemotaxis in a microfluidic device., Lab Chip. 8 (2008) 1292 
1299. doi:10.1039/b719788h.

[45] C.O. Lizama, A.C. Zovein, Polarizing pathways: Balancing endothelial polarity, permeability, and lumen formation, Exp. Cell Res. 319 (2013) 1247-1254.

4 doi:10.1016/j.yexcr.2013.03.028.

5 [46] Z.H. Chohan, A. Rauf, S. Noreen, A. Scozzafava, C.T. Supuran, Antibacterial cobalt(II), nickel(II) and zinc(II) complexes of nicotinic acid-derived schiff-bases, J. Enzyme Inhib. Med. Chem. 17 (2002) 101-106. doi:10.1080/14756360290024209.

9 [47] B.B. Finlay, P. Cossart, Exploitation of mammalian host cell functions by bacterial pathogens., Science. 276 (1997) 718-25. doi:10.1126/SCIENCE.276.5313.718.

11 [48] S. Lebeer, J. Vanderleyden, S.C.J. De Keersmaecker, Host interactions of probiotic 12 bacterial surface molecules: comparison with commensals and pathogens, Nat.

13 Rev. Microbiol. 8 (2010) 171-184. doi:10.1038/nrmicro2297. 
a)
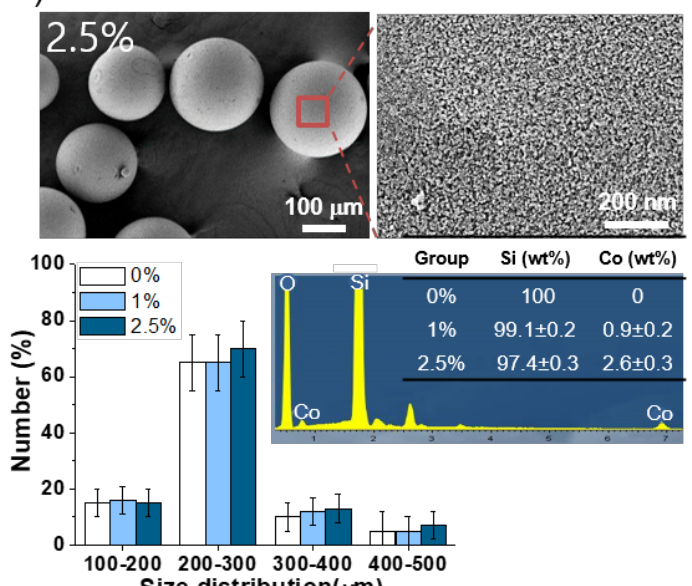

c)
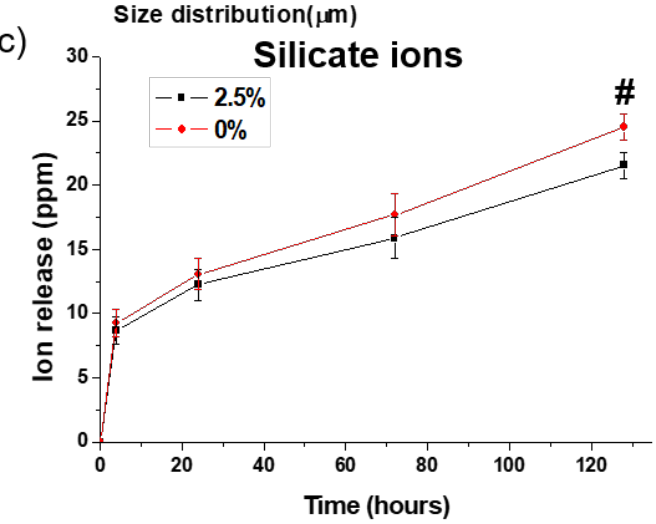

b)
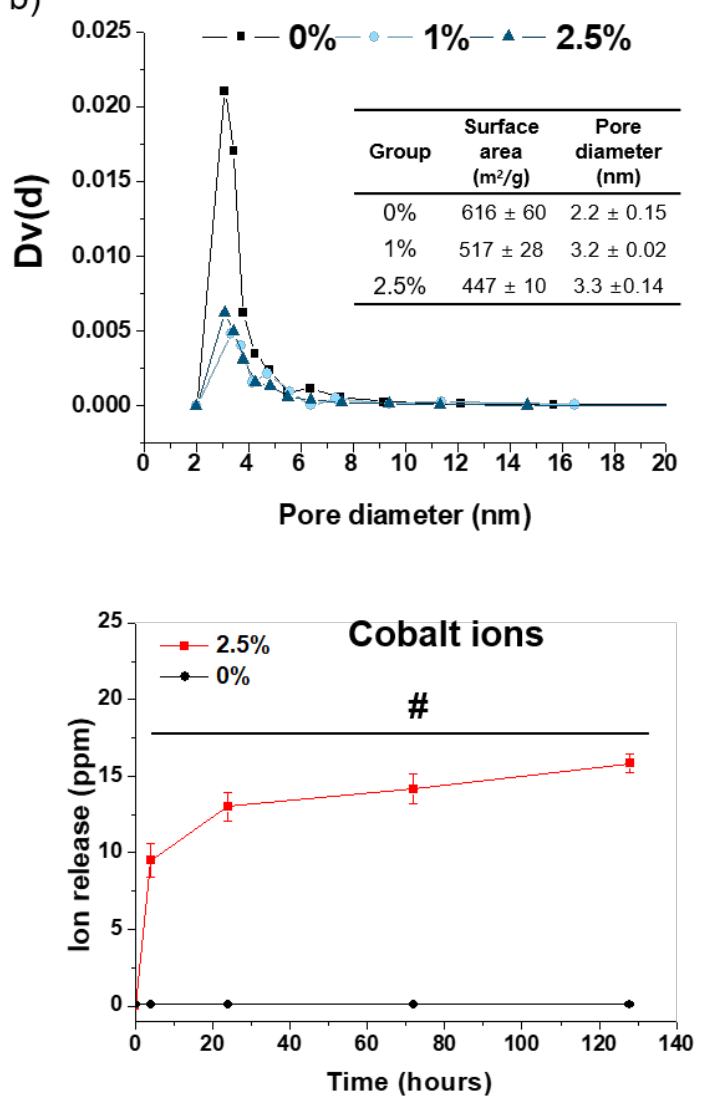

3 Figure 1. Characterization of $\mathrm{Si}(0 \%)$ and $\mathrm{Si}-\mathrm{Co}(1 \%$ or $2.5 \%)$ microcarriers. (a)

4 Spherical morphology, size distrubution, and their composition were characterized by

5 SEM with EDS. (b) BET measurements showed comparable pore size distributions and

6 surface areas. (c) Degradable microspheres presented controlled ion release, studied by

7 ICP-AES. Data are presented as the mean $\pm \mathrm{SD}(\mathrm{n}=3)$. Sharp (\#) indicates a statistically

8 significant difference compared to value in $0 \%$ group. 


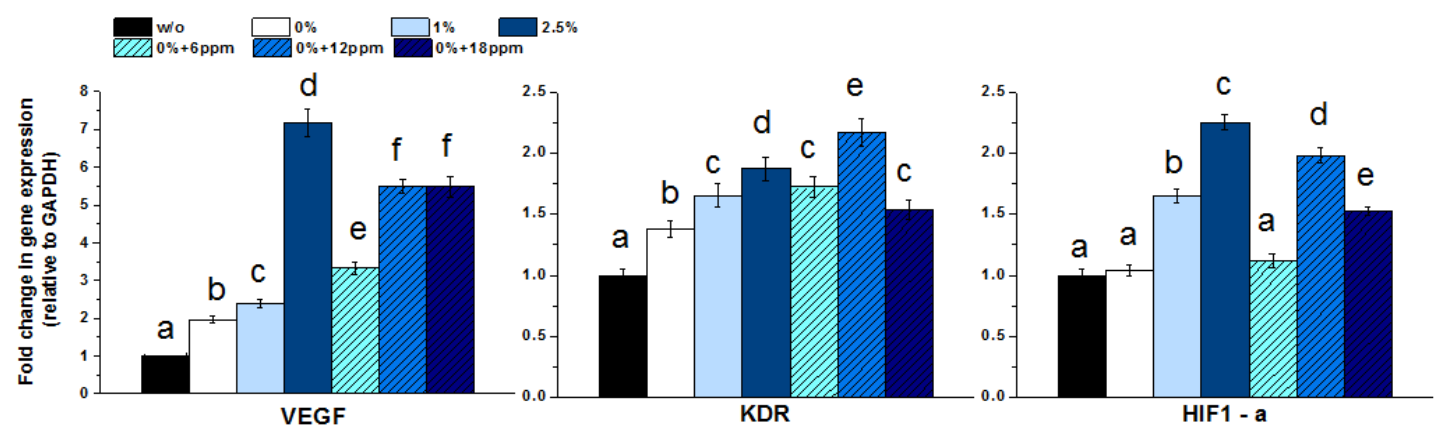

2 Figure 2. Effects of microcarriers and free Co ions on angiogenic gene expression in

3 HUVECs. Gene expression of VEGF, KDR and HIF1- $\alpha$ was quantified by qPCR after 24

$4 \mathrm{~h}$ of co-culturing with microcarriers $(10 \mathrm{mg} / \mathrm{mL})$ via incorporated or free cobalt ions

$5 \quad(6 \sim 18 \mathrm{ppm})$ for comparison. Significant upregulation of angiogenic gene expression was

6 revealed in microcarrier groups in the order of w/o $<0 \%<1 \%<2.5 \%$, similar to that

7 from free Co ions (12 18 ppm). Different letters in each graph indicate significant 8 differences between groups at the level of $\mathrm{P}<0.05(\mathrm{n}=3)$. 
a)
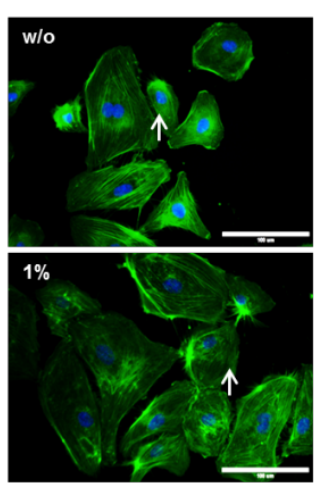

b)

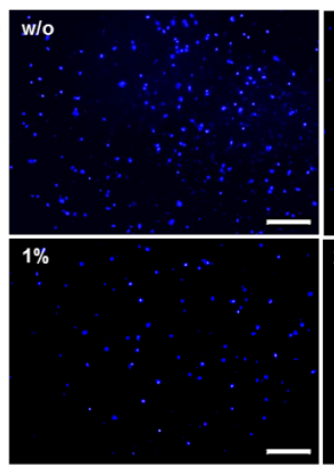

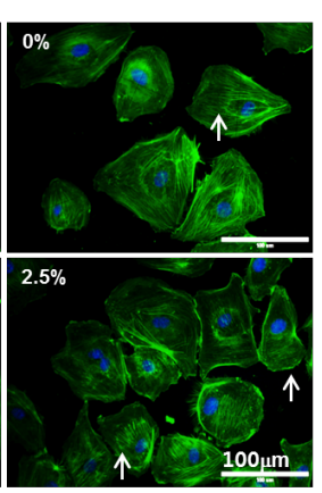

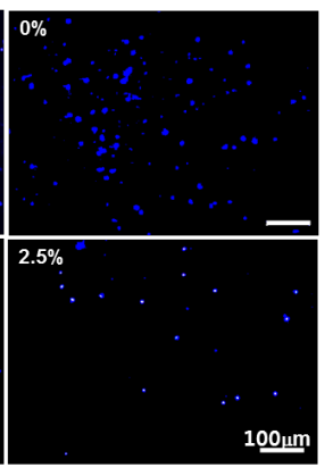

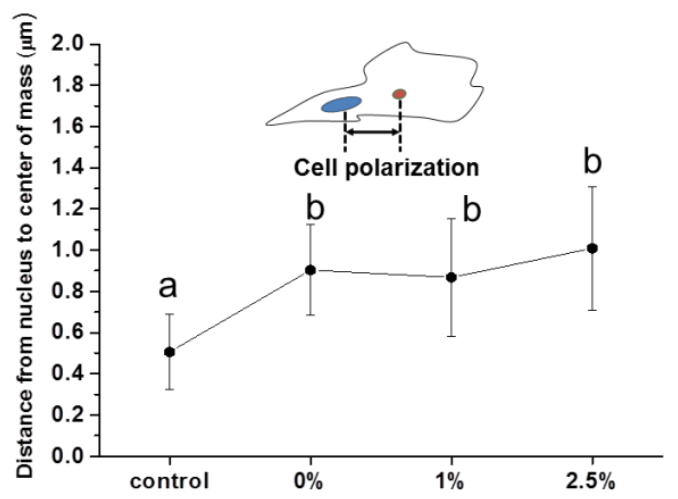

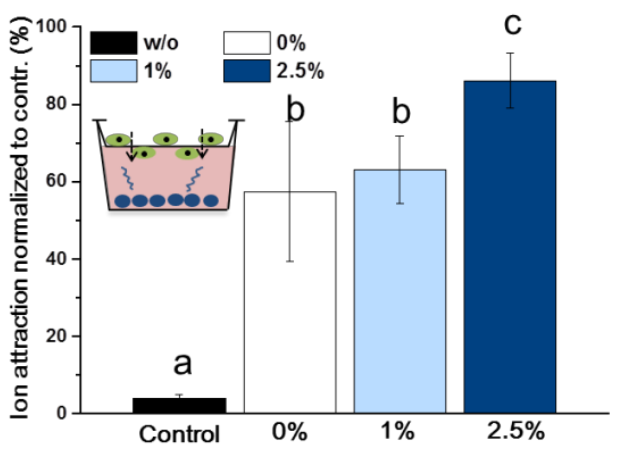

3 Figure 3. Enhanced HUVEC polarization and cell homing effects by ion attraction in 4 microcarriers. (a) Stained HUVECs (green (actin) and blue (DAPI)) were captured by 5 fluorescent microscopy after $4 \mathrm{~h}$ of co-culture with microspheres $(10 \mathrm{mg} / \mathrm{mL})$, and the

6 distance between the nucleus centre and the centre of mass was quantified by ImageJ

7 based on the captured image. Polarization was enhanced in the order of w/o $<0$ and $1 \%<$

$8 \quad 2.5 \%(\mathrm{P}<0.05)$. (b) Cell homing effects (1h) were negatively shown by the number of

9 DAPI (blue)-stained HUVECs in the top of the insert ( $8 \mu \mathrm{m}$ pore size). Fewer cells

10 remained in the $2.5 \%$ group than in other groups, indicating that more cells migrated via

11 pores to microspheres $(10 \mathrm{mg} / \mathrm{mL})$. Cells that migrated to the microsphere were

12 quantified based on initial cell numbers and captured images. The $2.5 \%$ group exhibited

13 greater cell homing than other groups $(\mathrm{P}<0.05)$. Different letters in each graph indicate

14 significant differences between groups at the level of $\mathrm{P}<0.05(\mathrm{n}=3)$. 
a)

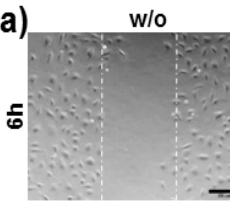

ลี

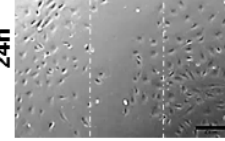

$1 \%$

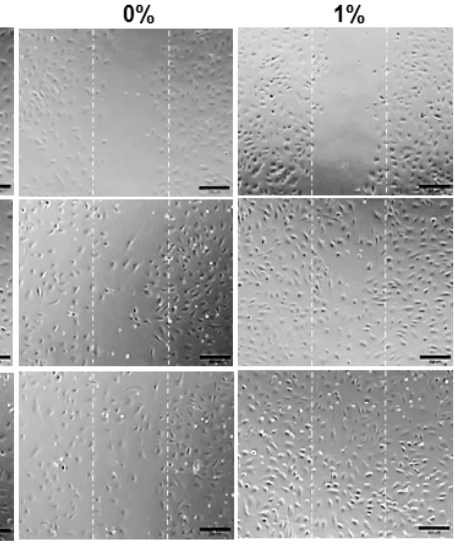

$2.5 \%$

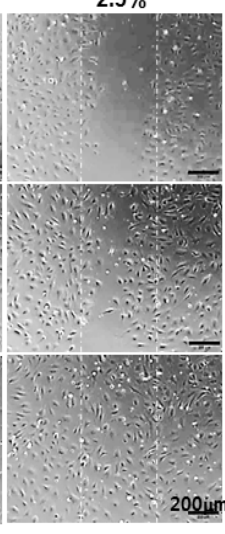

b)

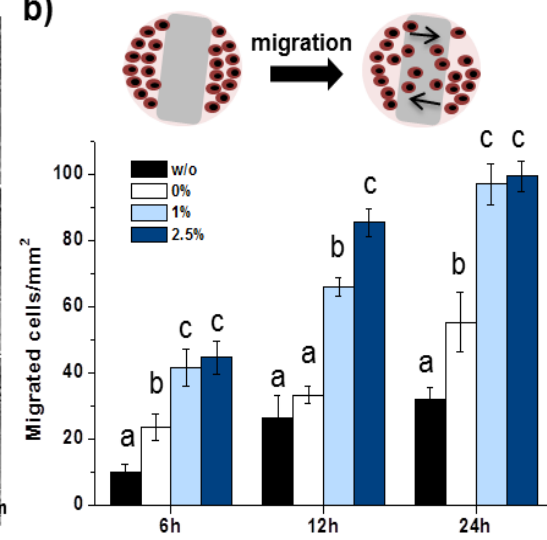

2 Figure 4. Enhanced HUVEC migration in the scratch assay. (a) Optical images of

3 migrated cells from each group at different time points (6, 12 and $24 \mathrm{~h})$ and (b) their

4 quantification. Cells that migrated to the scratched area were quantified per unit area

$5\left(\mathrm{~mm}^{2}\right)$, revealing an acceleration of cell migration under microsphere co-culture

6 conditions $(10 \mathrm{mg} / \mathrm{mL})$ after mitomycin B pretreatment $(2 \mathrm{~h})$ in the order of w/o $<0 \%<$

$7 \quad 1 \%<2.5 \%$. Different letters in each graph indicate significant differences between

8 groups at the level of $\mathrm{P}<0.05(\mathrm{n}=3)$. 
a)
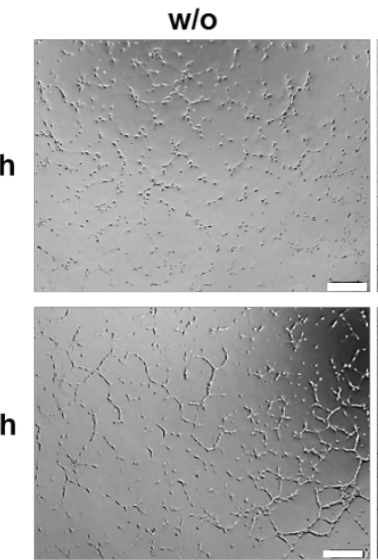

b)

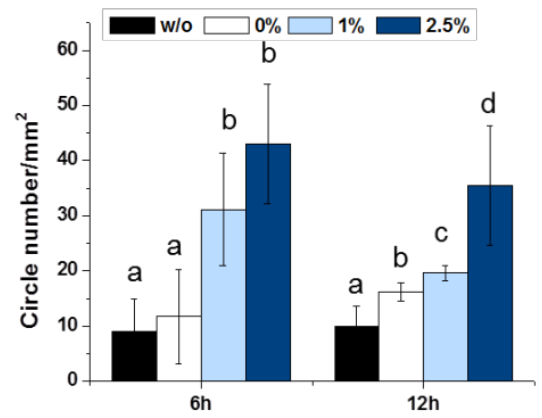

$1 \%$

$2.5 \%$
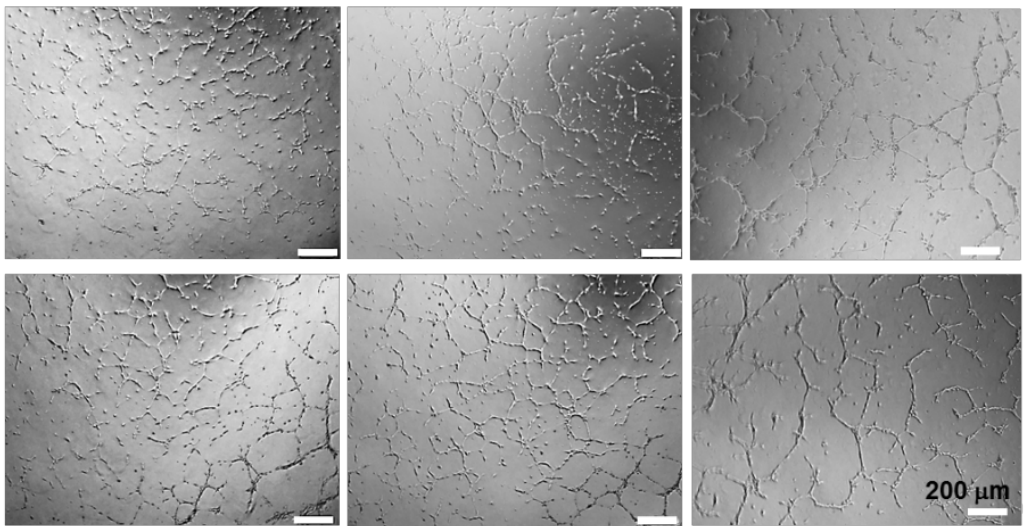

c)

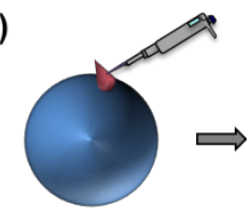

Matrigel covering

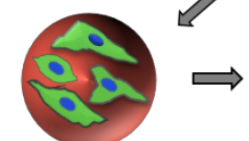

Cellular spreading
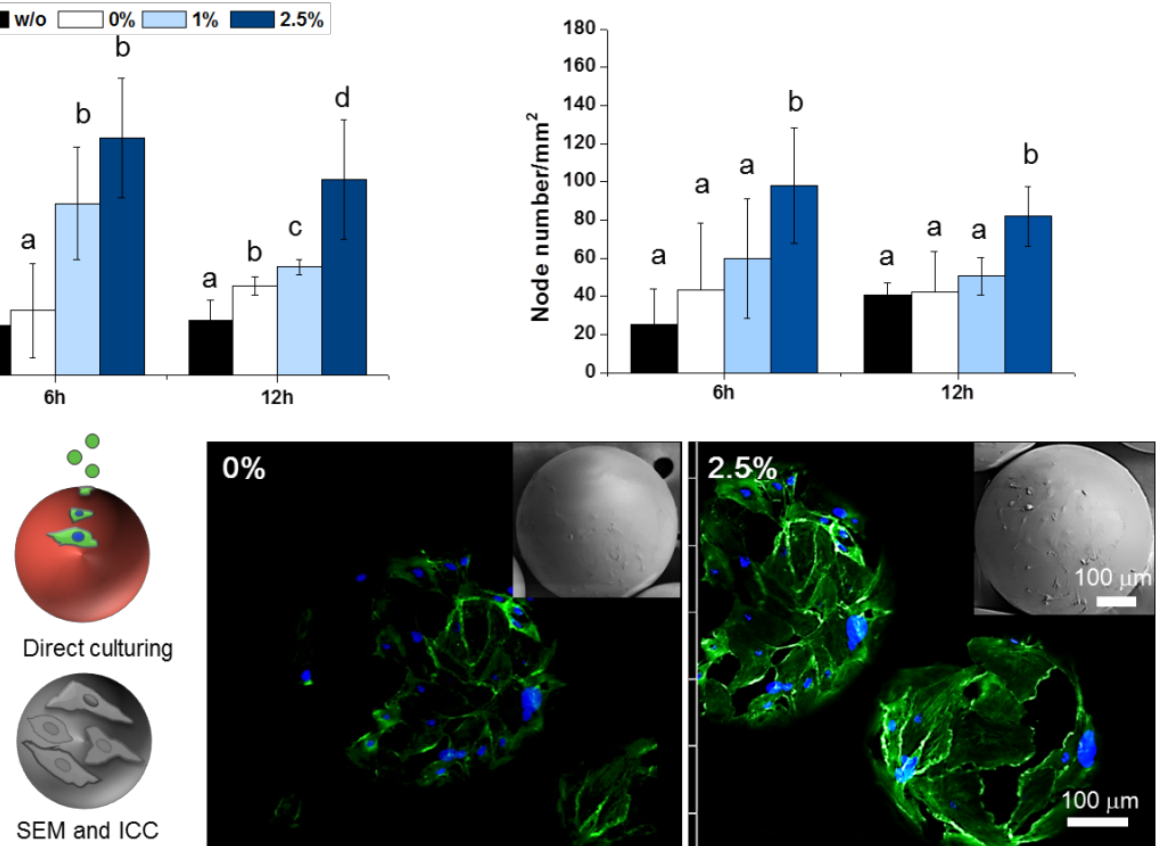

Figure 5. Effects of microcarriers $(10 \mathrm{mg} / \mathrm{mL})$ on HUVEC tubular network formation.

3 (a) Optical images of the tubular network of endothelial cells with different groups at

4 different time points (6 and $12 \mathrm{~h}$ ). (b) Node number and circle number were assessed

5 from optical images. Of the experimental groups, the 2.5\% group showed the most

6 excellent ability to form tubular networks. Different letters in each graph indicate

7 significant differences between groups at the level of $\mathrm{P}<0.05(\mathrm{n}=3)$. (c) Cell delivery

8 potential of microcarriers. Schematic illustration of the procedure coating the

9 microcarrier with Matrigel to deliver endothelial cells (HUVECs). F-actin (green) and

10 nucleus-stained (blue) images of endothelial cells delivered on the microcarriers with

11 SEM morphology after $24 \mathrm{~h}$. 
a)

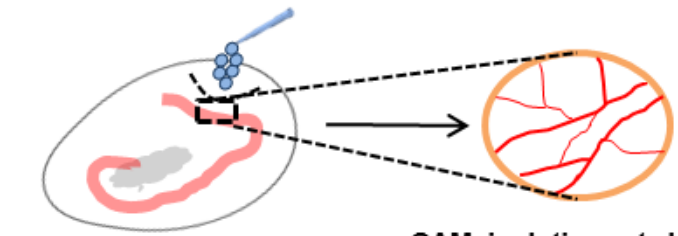

Implant CoMS at day 7

Original picture

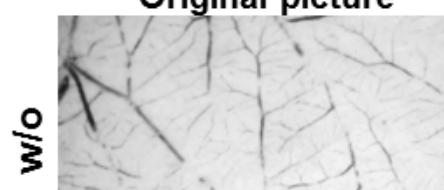

$\stackrel{\circ}{\circ}$
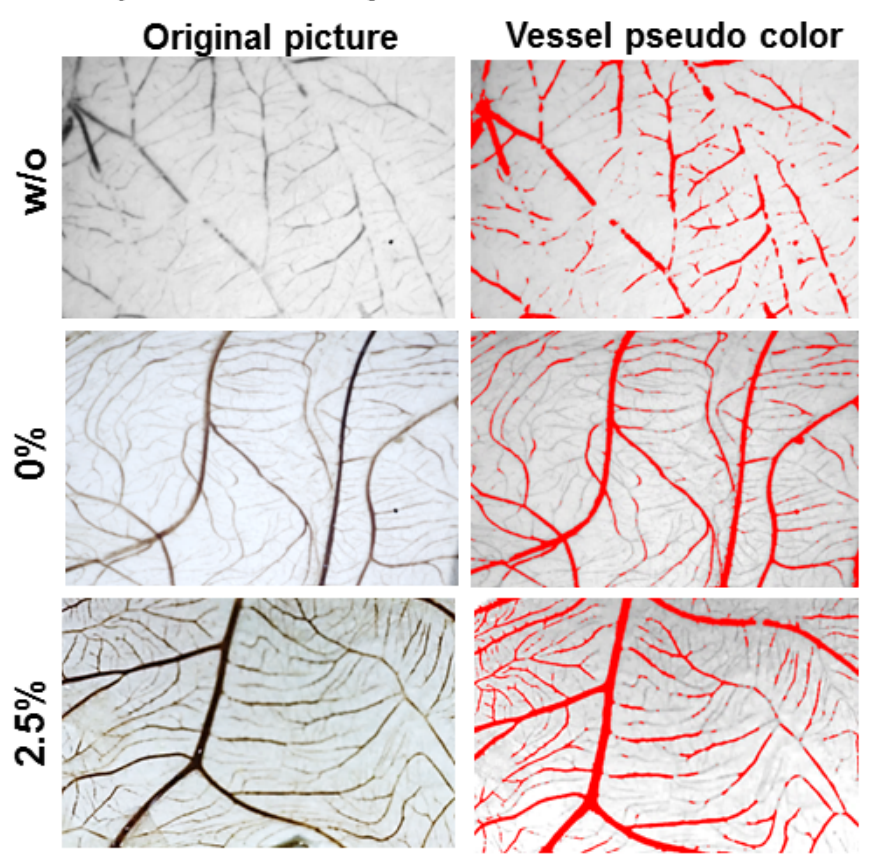

b)
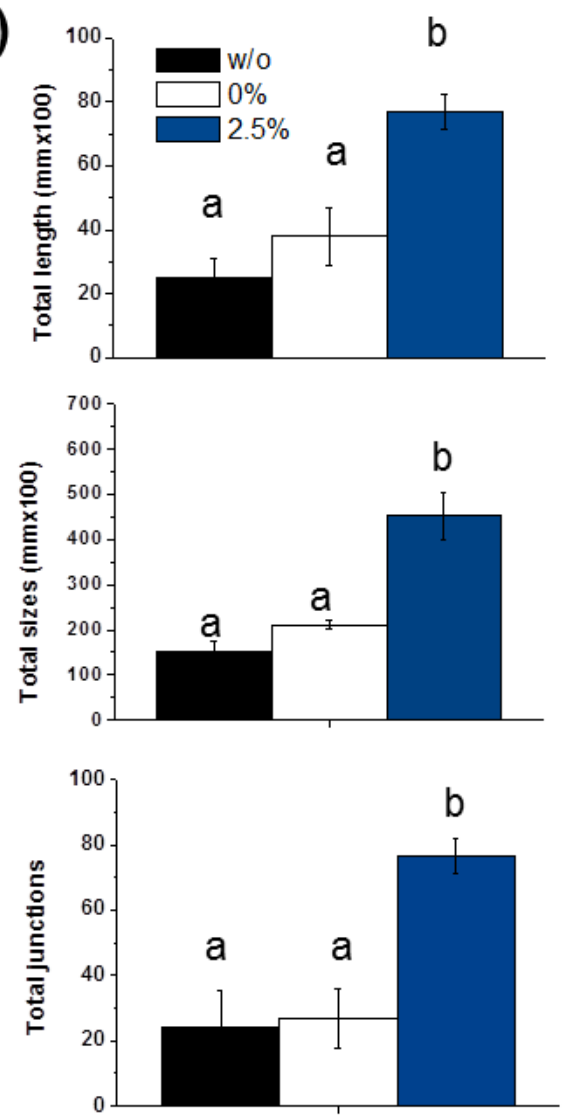

2 Figure 6. Ex vivo pro-angiogenic capacity from microcarriers (10 mg) in the CAM assay.

3 (a) Representative images of two groups are presented after 4 days of implantation, and

4 (b) pro-angiogenic effects were quantified by total tubular lengths, sizes and junctions,

5 revealing upregulation in the $2.5 \%$ group compared to other groups. Different letters in

6 each graph indicate significant differences between groups at the level of $\mathrm{P}<0.05(\mathrm{n}=3)$. 
a)

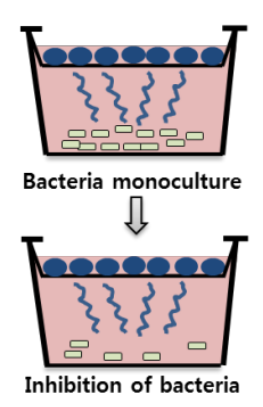

b) w/o
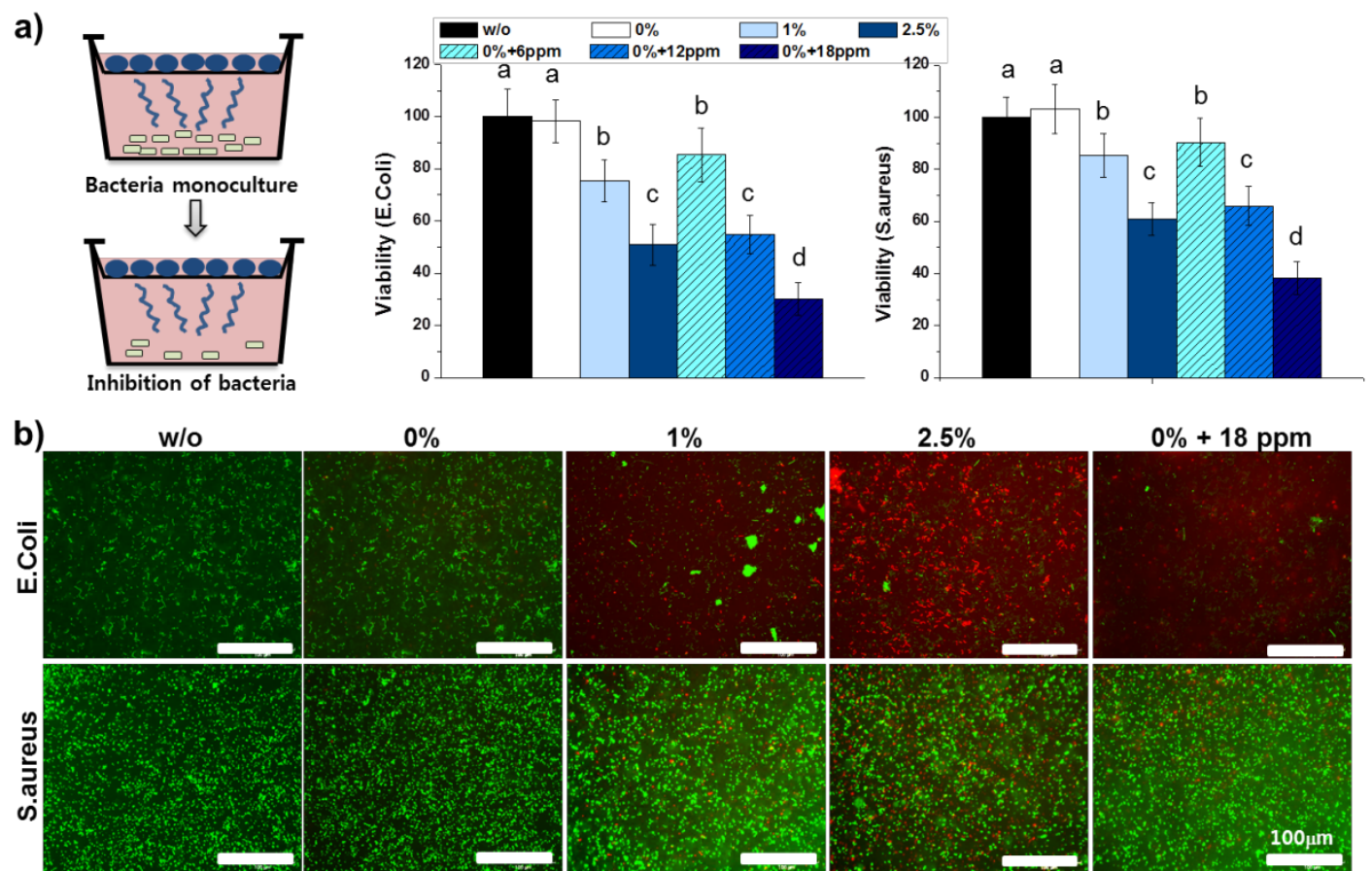

$1 \%$

$0 \%+18 \mathrm{ppm}$

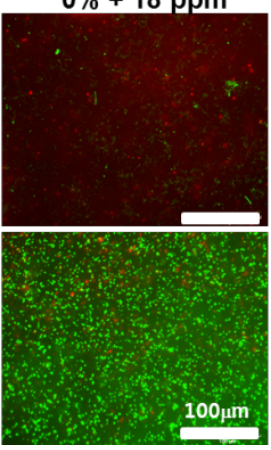

2 Figure 7. Indirect monoculture conditions using transwells between bacteria strains and

3 microcarriers indicated antibacterial effects of Co ion-releasing microcarriers on both

4 gram-negative (E. coli) and gram-positive ( $S$. aureus) model bacteria. (a) Inhibition of

5 bacterial $\left(1 \times 10^{7} / \mathrm{mL}\right)$ viability after $4 \mathrm{~h}$ of co-culturing with microcarriers $(10 \mathrm{mg} / \mathrm{mL})$

6 using transwells in a PrestoBlue assay. (b) Images of live (green) and dead (red) cells

7 confirmed bactericidal effects of $2.5 \%$ microcarriers, similar to the Co ion control.

8 Different letters in each graph indicate significant differences between groups at the level 9 of $\mathrm{P}<0.05(\mathrm{n}=5)$. 
Acta biomaterialia

a) Extraction
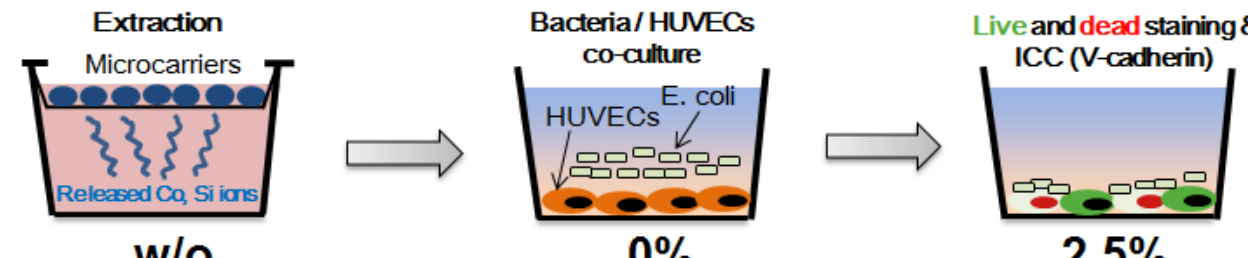

b) w/o
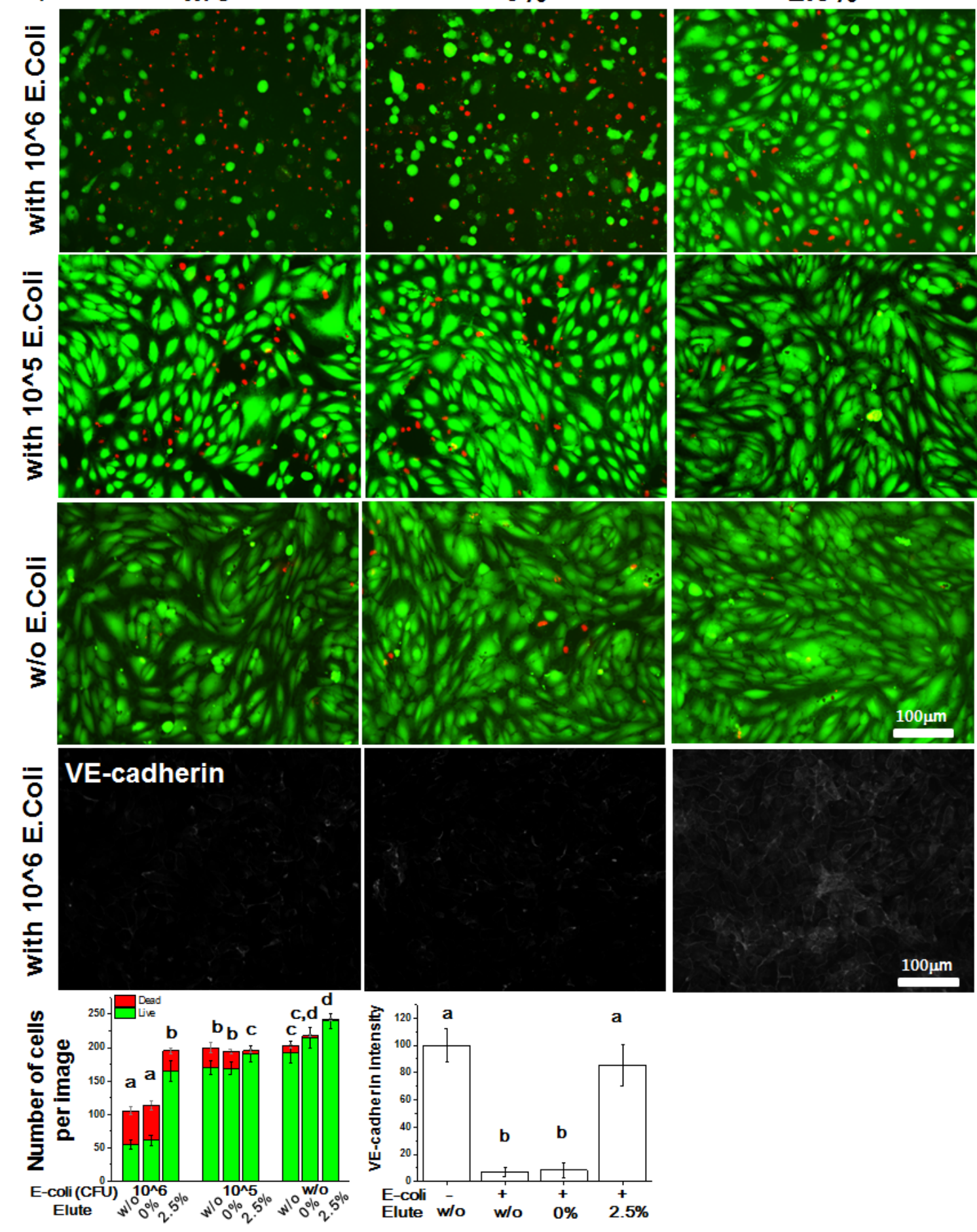

$100 \mu \mathrm{m}$
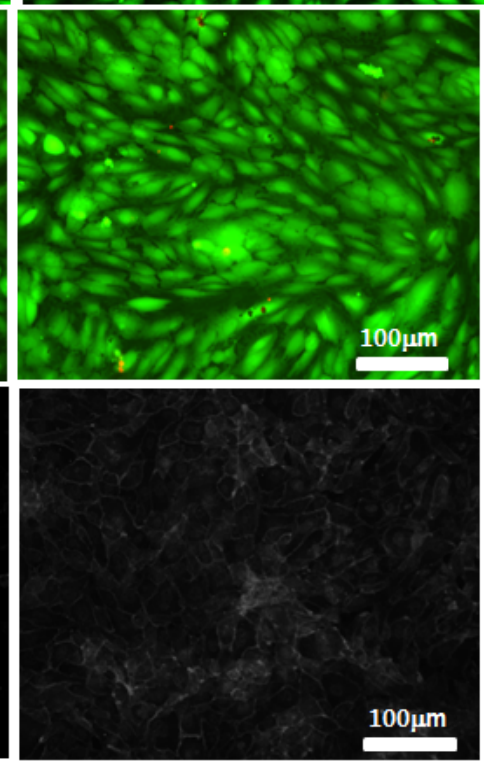
1 Figure 8. Co-culture of bacteria (E. coli) and HUVECs in media supplemented with

2 extraction from microcarriers. More live HUVECs with less dead numbers were detected

3 in the $2.5 \%$ compared to contr. (w/o) and $0 \%$. A number of live and dead HUVEC cells

4 was counted based on the colour and more live HUVECs with less dead numbers were

5 significantly detected in the $2.5 \%$ compared to contr. (w/o) and $0 \%$ in two different E.

6 coli CFU condition. VE-cadherin intensity was highly conserved in $2.5 \%$ while

7 compromised VE-cadherin expression was visualized and quantified in w/o and $0 \%$

8 group $(\mathrm{P}<0.05)$. Representative images are shown. Different letters in each graph indicate

9 significant differences between groups at the level of $\mathrm{P}<0.05(\mathrm{n}=5)$. Different letters in a

10 graph of 'number of cells per image' revealing comparison of live cells numbers between 11 groups.

12

13 
1 Supplement data
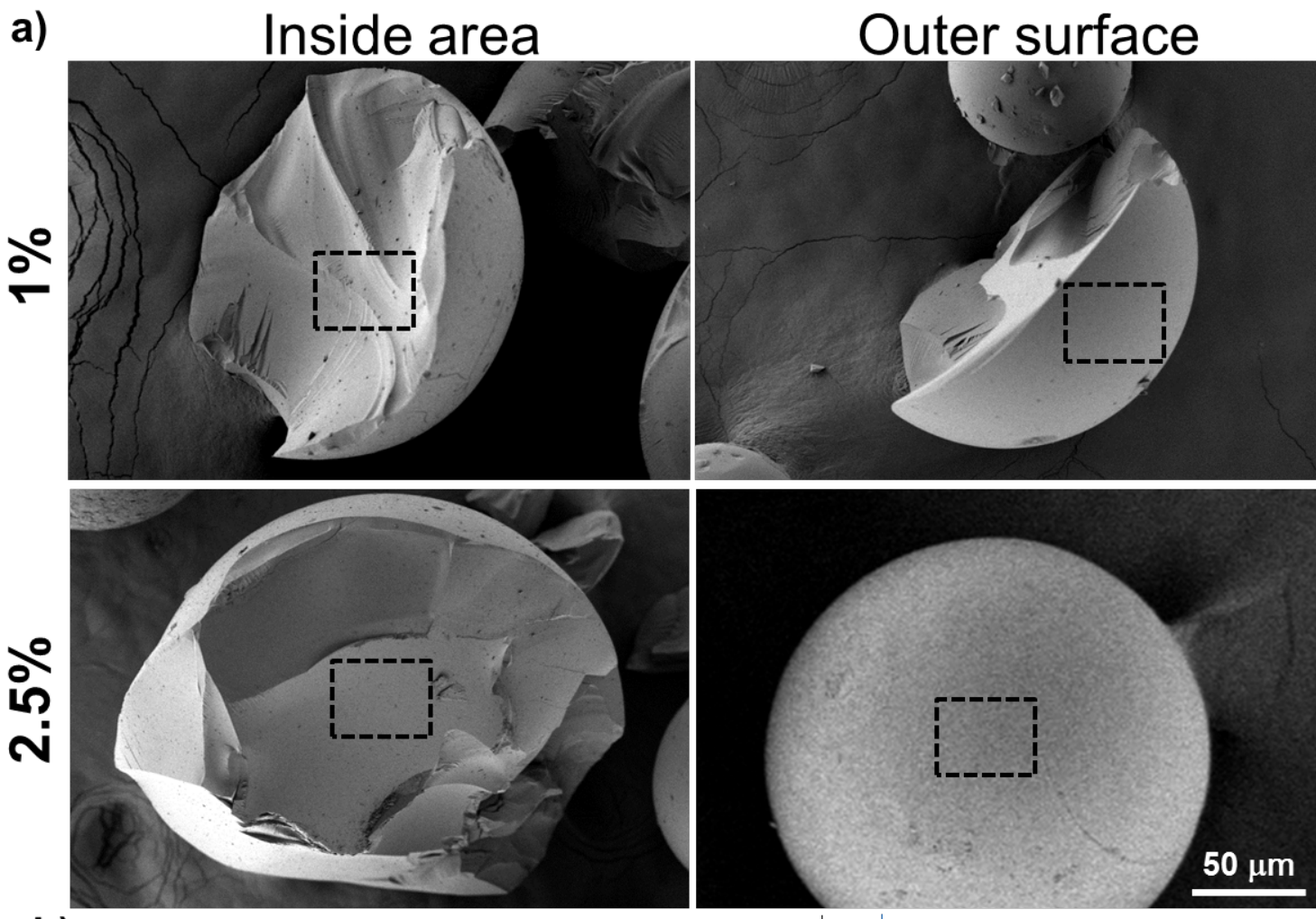

\begin{tabular}{ccc}
\hline b) & & \\
\hline Group & Si (wt $\%)$ & Co $(w t \%)$ \\
\hline $1 \%-I n s i d e$ & $99.2 \pm 0.3$ & $0.8 \pm 0.3$ \\
$1 \%-O u t e r$ & $99.1 \pm 0.2$ & $0.9 \pm 0.2$ \\
$2.5 \%$-Inside & $97.7 \pm 0.4$ & $2.3 \pm 0.4$ \\
\hline $2.5 \%$-Outer & $97.4 \pm 0.3$ & $2.6 \pm 0.3$ \\
\hline
\end{tabular}
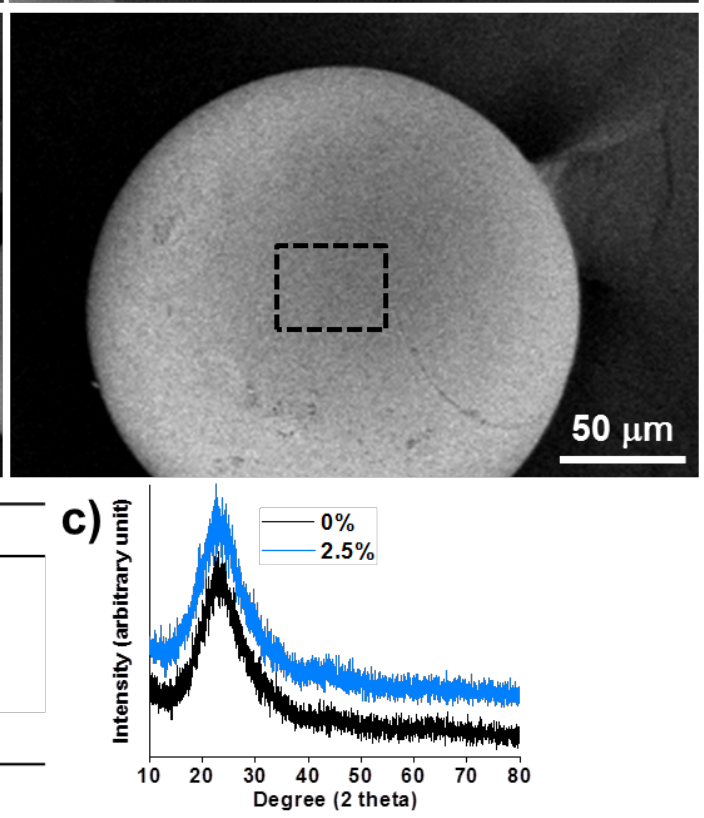

3 Supplementary data 1. (a) Inner and outer part of microsphere was visualized by SEM

4 and (b) their composition was characterized by EDS $(n=3)$. Inner structure was revealed

5 after being fractured by compressive force. Dotted line in (a) was analysed by EDS and

6 results were shown in (b). Equal composition is revealed between inner and outer part of

7 each microsphere ( 1 or $2.5 \%$ ). (c) XRD results present amorphous structure of the silica

8 network and there is no influence of the glass network due to lower concentration of 9 cobalt. 


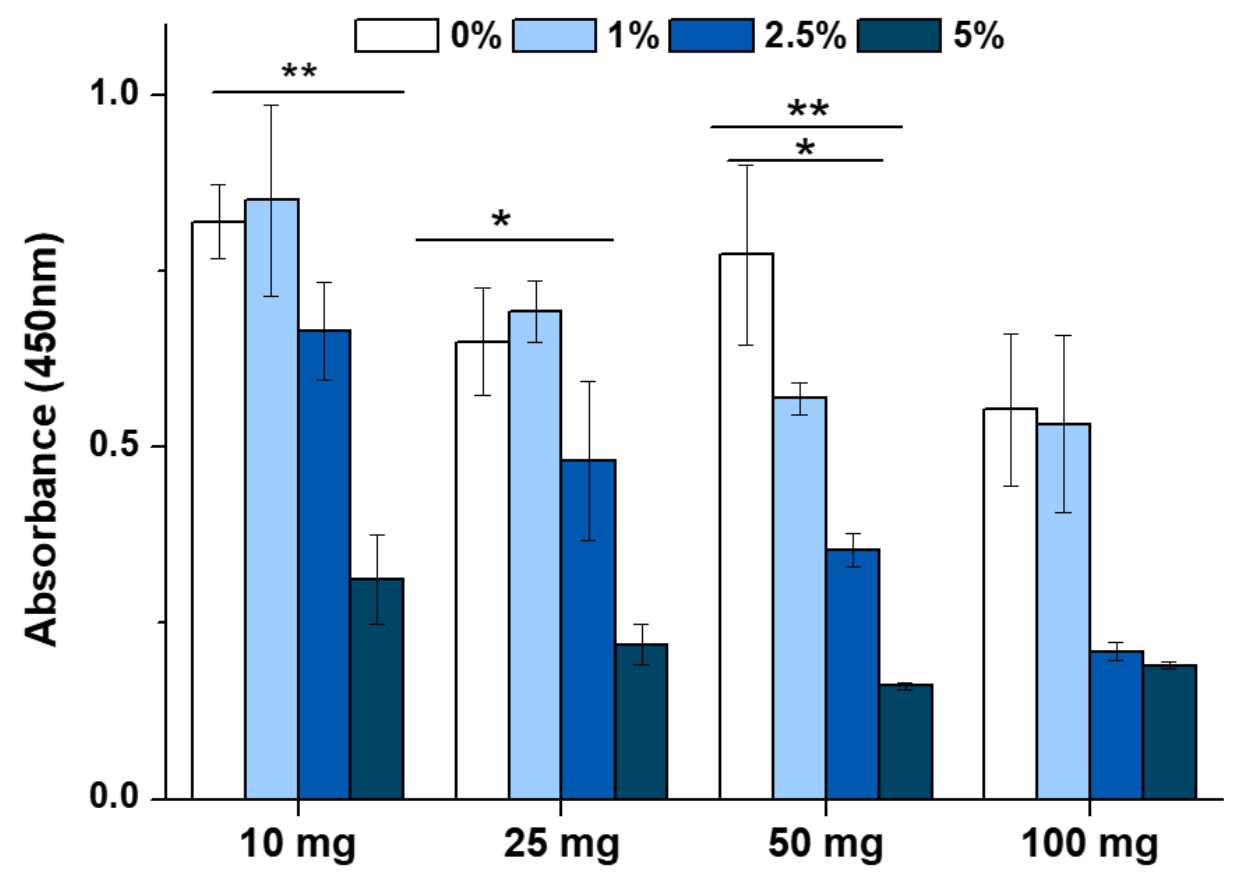

2 Supplementary data 2. Different amounts of microcarriers were evaluated for their 3 effects on cell proliferation by CCK assay $(* \mathrm{P}<0.05 \& * * \mathrm{P}<0.01, \mathrm{n}=5)$. Ten milligrams 4 of microcarriers was selected for concentration used in further biological assay and 5\% 5 was excluded among experimental groups.

6
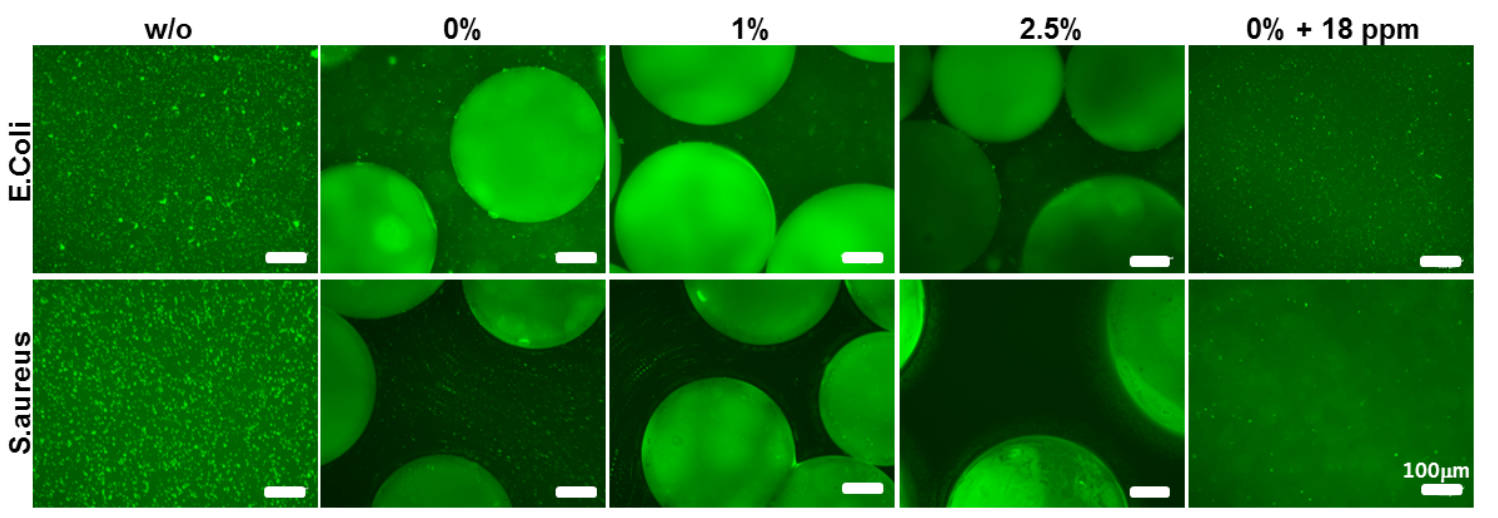

8 Supplementary data 3. Live and dead staining of bacteria using direct co-culture

9 conditions with microcarriers. Fewer live bacteria species were detected in the area

10 surrounding the $2.5 \%$ microcarriers for both the E. coli and $S$. aureus species $(\mathrm{n}=3)$.

11 Representative images with moving bacteria are shown. 


\section{Supplementary table}

2 Supplementary table 1. Detail of in vitro experiment

\begin{tabular}{|c|c|c|c|c|c|}
\hline Experiment & Cell number & Culture condition & Well & Number & Note \\
\hline Cell viability & $2.0 \times 10^{4}$ & $72 \mathrm{~h}$ & & $\mathrm{n}=5$ & Maximizing cytotoxicity \\
\hline qPCR & $1.0 \times 10^{5}$ & $24 \mathrm{~h}$ & & $\mathrm{n}=3$ & - \\
\hline Cell migration & $1.0 \times 10^{5}$ & $\begin{array}{l}24 \mathrm{~h} \text { of pre-culture } \\
\quad+6,12 \text { or } 24 \mathrm{~h}\end{array}$ & $\begin{array}{l}24 \text { well } \\
\left(2.0 \mathrm{~cm}^{2}\right)\end{array}$ & $n=3$ & - \\
\hline Cell polarization & $5.0 \times 10^{3}$ & $\begin{array}{l}4 \mathrm{~h} \text { of pre-culture } \\
+1 \mathrm{~h}\end{array}$ & & $\mathrm{n}=3$ & For single cell analysis \\
\hline Ion attraction & $5.0 \times 10^{3}$ & $\begin{array}{l}4 \mathrm{~h} \text { of pre-culture } \\
+1 \mathrm{~h}\end{array}$ & $\begin{array}{c}\text { Insert } \\
\left(0.33 \mathrm{~cm}^{2}\right)\end{array}$ & $\mathrm{n}=3$ & $\begin{array}{l}\text { Considering insert area and } \\
\text { maximizing ion attraction }\end{array}$ \\
\hline Tubular formation & $3.0 \times 10^{4}$ & 6 and $12 \mathrm{~h}$ & $\begin{array}{c}24 \text { well } \\
\text { on matrigel }\end{array}$ & $\mathrm{n}=3$ & Optimizing cell number \\
\hline $\begin{array}{l}\text { Cell-bacteria co- } \\
\text { culture }\end{array}$ & $2.0 \times 10^{4}$ & $\begin{array}{l}24 \mathrm{~h} \text { of pre-culture } \\
+6 \mathrm{~h} \text { with bacteria }\end{array}$ & $\begin{array}{l}96 \text { well } \\
\left(0.33 \mathrm{~cm}^{2}\right)\end{array}$ & $\mathrm{n}=3$ & Optimizing cell number \\
\hline
\end{tabular}

